NBER WORKING PAPER SERIES

\title{
CATERING THROUGH NOMINAL SHARE PRICES
}

\author{
Malcolm Baker \\ Robin Greenwood \\ Jeffrey Wurgler \\ Working Paper 13762 \\ http://www.nber.org/papers/w13762
NATIONAL BUREAU OF ECONOMIC RESEARCH
1050 Massachusetts Avenue
Cambridge, MA 02138
January 2008

For helpful comments we thank Yakov Amihud, Lauren Cohen, Ken French, Sam Hanson, Harrison Hong, Byoung-Hyoun Hwang, Eric Kelley, Owen Lamont, Ulrike Malmendier, Andrei Shleifer, Erik Stafford, Dick Thaler, and seminar participants at Arizona State, Copenhagen Business School, Darmouth, Helsinki School of Economics, Kellogg, the NBER Behavioral Finance conference, the Norwegian School of Management, NYU Stern, Penn State, Stockholm School of Economics, and the University of Arizona. We thank Jay Ritter for providing data. Baker and Greenwood gratefully acknowledge financial support from the Division of Research of the Harvard Business School. The views expressed herein are those of the author(s) and do not necessarily reflect the views of the National Bureau of Economic Research.

NBER working papers are circulated for discussion and comment purposes. They have not been peerreviewed or been subject to the review by the NBER Board of Directors that accompanies official NBER publications.

(C) 2008 by Malcolm Baker, Robin Greenwood, and Jeffrey Wurgler. All rights reserved. Short sections of text, not to exceed two paragraphs, may be quoted without explicit permission provided that full credit, including $(\subset$ notice, is given to the source. 
Catering Through Nominal Share Prices

Malcolm Baker, Robin Greenwood, and Jeffrey Wurgler

NBER Working Paper No. 13762

January 2008

JEL No. G12,G3

\begin{abstract}
$\underline{\text { ABSTRACT }}$
We propose and test a catering theory of nominal stock prices. The theory predicts that when investors place higher valuations on low-price firms, managers will maintain share prices at lower levels, and vice-versa. Using measures of time-varying catering incentives based on valuation ratios, split announcement effects, and future returns, we find empirical support for the predictions in both time-series and firm-level data. Given the strong cross-sectional relationship between capitalization and nominal share price, an interpretation of the results is that managers may be trying to categorize their firms as small firms when investors favor small firms.
\end{abstract}

Malcolm Baker

Baker Library 261

Harvard Business School

Soldiers Field

Boston, MA 02163

and NBER

mbaker@hbs.edu

Robin Greenwood

Harvard Business School

Morgan Hall 479

Soldiers Field Road

Boston, MA 02163

rgreenwood@hbs.edu
Jeffrey Wurgler

Stern School of Business, Suite 9-190

New York University

44 West 4th Street

New York, NY 10012

and NBER

jwurgler@stern.nyu.edu 
In frictionless and efficient stock markets, there is no optimal nominal (per-share) stock price. A firm's board of directors may choose to split to manage the nominal share price and number of shares outstanding but cannot change its overall market value through these means. Yet boards typically do manage their firm's nominal share price. Theories offered to explain share price management include that trading costs depend on nominal prices (Dolley (1933), Angel (1997)), that splits signal inside information (Asquith, Healy, and Palepu (1989), Brennan and Copeland (1988)), or that prices in certain ranges simply constitute a market norm (Benartzi, Michaely, Thaler, and Weld (2007)).

In this paper, we propose a different theory of nominal share prices. The catering theory of nominal share prices sees share price management as an effort to obtain higher valuations that investors may be temporarily placing on stocks at different price ranges. The theory predicts that splits will be more frequent, and to lower prices, when the valuations of low-priced firms are attractive relative to the valuations of high-priced firms.

To explain managerial behavior, the catering theory requires only that managers believe that nominal prices matter to investors. While the majority of managers subscribe to this belief (Baker and Gallagher (1980)), the theory gains further motivation from evidence that, contrary to efficient markets, return characteristics actually are affected by nominal price. Green and Hwang (2007) find that stocks that split experience sudden increases in their comovement with lowerpriced stocks. Ohlson and Penman (1985) find that stocks that split experience large increases in volatility; thus, as splitting stocks comove more with low-price, generally smaller-cap stocks, they inherit their higher volatility as well. Lakonishok, Shleifer, and Vishny (1992) and Gompers and Metrick (2001) show that individual investors hold lower-price stocks than institutions, suggesting a segmented market. Black (1986) also views low-price stocks as subject to greater 
noise trading. Investors thus appear to categorize stocks in part based on price, and this affects returns, much as the addition or deletion of a stock from an index affects returns in Barberis, Shleifer, and Wurgler (2005), Greenwood (2007a), and Greenwood and Sosner (2007).

A case study introduces our main ideas. Figure 1 plots the share price of Applied Materials, Inc. from 1980 through 2004. Applied Materials enjoyed success in this period and split its shares nine times. However, far from maintaining a constant share price, the company split to nine different prices, ranging from $\$ 15$ all the way to $\$ 88$, through both 2 -for-1 and 3-for2 splits. Catering predicts splits to lower prices when lower-priced shares are in favor. Consistent with this prediction, the figure illustrates a close connection between the post-split share price and a relative valuation measure that we refer to as the "low-price premium," the log difference between the average market-to-book ratio of low-nominal-price firms and that of high-nominalprice firms. In the figure, the series is inverted so that higher values suggest an investor preference for higher-priced stocks. Simply put, the figure shows that when low-priced stocks enjoyed relatively high valuations, Applied Materials maintained a lower share price, and when high-priced stocks enjoyed high valuations, the company maintained a higher share price.

In our empirical work, we use three time series proxies for catering incentives based on annual data from 1963 through 2006. We just described the low-price premium. There is a strong cross-sectional relationship between size and share price, as in Dyl and Elliott (2006) and Benartzi et al. (2007), suggesting the possibility that catering-minded splitters may be trying to portray themselves not as low-priced firms per se but rather as small-cap firms. We therefore construct a "small-cap premium" as the average market-to-book ratio on small-cap firms relative to the average market-to-book ratio on large-cap firms. As a third measure of the time-varying incentive to reduce prices, we use the average announcement effect of recent splits. Greenwood 
(2007b) finds that high announcement effects for Japanese splitters are associated with more splits and higher split ratios in subsequent quarters. Both results are consistent with catering.

A simple accounting framework for nominal share prices suggests testing whether four components of active price management depend on catering incentives: the binary decision to split in a given period; the net change in price due to active price management in a given period; the price chosen by splitters; and the price chosen at the IPO ${ }^{1}$ We perform these tests using both time-series and firm-level data. Note that IPOs are a particularly good laboratory in which to look for catering effects because newly public firms must actively choose a share price and they retain no legacy of any particular historical share price.

We find strong empirical support for the catering predictions. In terms of univariate time series regressions, our proxies for catering incentives explain up to $30 \%$ of the annual variation in the frequency of stock splits, with more firms splitting when low-priced or small-cap firms have higher valuations. The average net change in price across firms is also lower when investors favor lower-priced firms. Of course, prices are ultimately what we seek to explain. Catering incentives explain up to $75 \%$ of time variation in $(\log )$ IPO offer prices and $78 \%$ of time variation in (log) first-day closing prices, with firms going public at higher prices when catering incentives point that direction. Perhaps most broadly, catering proxies also explain up to $52 \%$ of the time variation in $(\log )$ post-split prices chosen by splitters. It seems unlikely that theories based on transaction costs or asymmetric information could achieve comparable explanatory power. The effects are robust to controlling for overall average prices and recent returns, other determinants of splits.

\footnotetext{
${ }^{1}$ To be clear, the nominal price stability that Benartzi et al. (2007) emphasize is stability relative to the enormous growth in other nominal prices in the economy. The average prices selected by stocks that split, the average prices selected by IPOs, and average nominal stock prices in general have varied by a factor of two to three over the last few decades. We address this variation.
} 
We consider several robustness tests for the regressions involving post-split prices, such as subsample splits, time trends, difference specifications, and so forth, with little change in the results. One interesting result that emerges is that catering incentives affect post-split prices only for larger firms. That is, the post-split price results reflect large firms trying to "act small" at opportune times. However, the results for IPO prices involve smaller, younger firms, so in that sense firms respond to catering concerns at multiple points in their life cycle. We also conduct robustness tests using firm-level data. This controls for changes in the composition of firms that might confound aggregate time-series tests. We find that proxies for catering incentives have incremental explanatory power for the various components of active price management when examined at the firm level, after controlling for a suite of firm- and industry-level characteristics.

Our final tests involve future stock returns. As noted above, it is not required that share prices be inefficient in order for catering to explain managerial behavior. Managers may cater in vain to an efficient market, not understanding that the valuations of low- and high-priced stocks differ for fundamental reasons. Nonetheless, we treat subsequent stock returns as proxies for the correction of ex ante mispricing and ask whether observed split patterns are consistent with the successful pursuit of misvaluation. Perhaps surprisingly, given our relatively short time series, the evidence is consistent with this view. High split frequencies and low post-split prices portend significantly lower future returns on small stocks versus large stocks and on low-priced stocks versus high-priced stocks.

In summary, nominal share prices are influenced by catering incentives. One question that the results raise, and that we leave to future work, is why nominal share prices matter to investors. Institutional trading frictions may play a role. The psychology of stock price levels is unexplored. Bernartzi et al (2007) suggest that stock prices constitute a norm. Perhaps some 
investors suffer from a nominal illusion in which they perceive that a stock is cheaper after a split, has more "room to grow" ( $\$ 10$ is farther from infinity than $\$ 25$ is), or has "less to lose" ( $\$ 10$ is closer to zero than $\$ 25$ is). Alternatively, perhaps they naively equate low nominal prices with small capitalization. Given the strong cross-sectional correlation between price and capitalization, and the fact that for individual investors it is a bit harder to obtain capitalization data than a price quote, this is not an entirely unreasonable heuristic. But managers of large caps may be able to exploit it. More generally, investors may categorize stocks according to price, so that a change in price can potentially lead to an increase in attention or investor recognition in the sense of Merton (1987). Whatever the mechanism, our particular results suggest time variation. Occasionally, investors as a group shift focus to different price categories. ${ }^{2}$ Or, equivalently clienteles with a particular focus in terms of stock price shift in importance over time. $^{3}$

The paper adds nominal share prices to a list of managerial decisions that may be shaped by catering influences. ${ }^{4}$ Baker and Wurgler (2004a,b) and Li and Lie (2006) consider catering via dividend policy. Cooper, Dimitrov and Rau (2001) and Cooper, Korana, Osobov, Patel, and Rau (2004) find evidence that corporate names can be shaped by catering considerations. Greenwood (2007b) finds that firms in Japan are more likely to announce stock splits following a period when stock splits have generated high announcement returns. Polk and Sapienza (2006) suggest that corporate investment decisions are shaped by catering considerations. Aghion and Stein (2006) view catering as an influence on the strategic decision to cut costs or maximize

\footnotetext{
${ }^{2}$ For example, see Bikhchandani, Hirshleifer, and Welch (1992) for a model of fads and customs.

${ }^{3}$ Odean (1999), Hirshleifer and Teoh (2002), and Barber and Odean (2007) emphasize that individual investors as a group limit their search for stocks to those that catch their attention. Nominal prices and splits may play a role in attracting individual investor attention, and thus stimulating demand.

${ }^{4}$ Somewhat related, Hong, Wang, and Yu (2007) suggest that firms can directly influence the supply and demand conditions in their own securities by repurchasing shares.
} 
sales growth. Baker, Ruback, and Wurgler (2004) suggest that time-varying investor preferences for the conglomerate form may help to explain the rise and subsequent dismantling of conglomerates. Unlike some of these applications, nominal share prices and stock splits offer a clean test of catering because they aren't tied up with any "real" motivation.

The paper proceeds as follows. Section I outlines the methodology and main hypotheses. Section II shows time-series tests. Section III offers firm-level tests. Section IV examines return predictability. Section V concludes.

\section{Methodology}

We are interested in explaining the active management of stock prices, in particular in identifying decisions that may be motivated by catering. The active management of stock prices has several components. We start by introducing a general accounting framework for share price management and then describe the main hypotheses.

\section{A. Accounting for share prices}

Stock prices are initially set at the IPO. Subsequently, active price setting happens through the choice of how often to split and at what ratio. Ignoring dividends for the moment, stock prices are determined as follows. Prices $P$ typically grow by the stock return $R$. The manager of firm $i$ can lower or raise the end of period price by choosing to split the stock:

$$
P_{i, t}=P_{i, t-1} \cdot\left(1+R_{i, t}\right) \cdot\left(1+S_{i, t} \cdot N_{i, t}\right)
$$

where $S$ is an indicator variable, equal to one if the manager decides to split the stock, and $N$ is the inverse of the split ratio minus one. For example, in a typical 2-for- 1 stock split, $N$ is equal to -0.5 . We can express this in logs as follows:

$$
p_{i, t}=p_{i, t-1}+r_{i, t}+\log \left(1+S_{i, t} \cdot N_{i, t}\right) \equiv p_{i, t-1}+r_{i, t}+m_{i, t} \approx p_{i, t-1}+r_{i, t}+s_{i, t} n
$$


where $p$ is the $\log$ price, $r$ is the $\log$ total return, and $m$ is the net effect of splitting activity between time $t$ and $t+1$. If the split ratio, and therefore $N$, does not vary over time - this is approximately the case empirically - then $s$ is simply an indicator variable for splits and $n$ is a constant, equal to the $\log$ of $1+N$, and the approximation in equation (2) is exact.

In addition to the explicit effect of splitting through $s$ and $n$, the manager is implicitly controlling $p$ through splitting decisions in prior periods. In that spirit, we can substitute for $p_{i, t-1}$ :

$$
p_{i, t} \approx \sum_{k=0}^{T_{i}} r_{i, t-k}+s_{i, t-k} n+p_{i, I P O}
$$

where $T$ is the number of periods since firm $i$ 's initial public offering.

Dividend policy can be treated in one of two ways. It can be lumped into active price selection by using total returns in the equations above or it can be taken as exogenous by using only the capital gains portion of returns in the equations above. We take the latter approach, focusing on the role of splits.

Our focus in the empirical tests is on the aggregate determinants $\mathbf{x}$ and, to a lesser extent, the firm level determinants $\mathbf{w}$ of active price selection. We take returns as given and examine the determinants of $p_{I P O}, s$ and $m$ in the following four specifications. In each case, we look at firm level and market wide data. The initial measure of price selection is the IPO price:

$$
p_{i, I P O}=f\left(\mathbf{w}_{i, I P O}, \mathbf{x}_{t-1}\right)+u_{i, I P O} \text { or, at the market level, } p_{t, I P O}=f\left(x_{t-1}\right)+u_{t}
$$

The narrowest measure of price selection following the IPO is simply the indicator variable $s$ :

$$
s_{i, t}=f\left(\mathbf{w}_{i, t-1}, \mathbf{x}_{t-1}\right)+u_{i, t} \text { or } s_{t}=f\left(\mathbf{x}_{t-1}\right)+u_{t}
$$

We then expand this to include the combined effect of $s$ and $n$ :

$$
m_{i, t}=p_{i, t}-p_{i, t-1}-r_{i, t}=f\left(\mathbf{w}_{i, t-1}, \mathbf{x}_{t-1}\right)+u_{i, t} \text { or } m_{t}=f\left(\mathbf{x}_{t-1}\right)+u_{t}
$$

The broadest measure of price selection is the price level itself: 


$$
p_{i, t}=f\left(\sum_{k=0}^{T_{i}} r_{i, t-k}, \mathbf{w}_{i, t-1}, \mathbf{x}_{t-1}\right)+u_{i, t} \text { or } p_{t}=f\left(\sum_{k=0}^{T} r_{t-k}, \mathbf{x}_{t-1}\right)+u_{t}
$$

For the IPO price, we of course focus on firms that have just listed. For the price level, we focus in similar spirit on firms that have split in period $t$. These firms have made an active decision within period $t$ and so the price reflects an explicit choice, rather than simply managerial inertia. We also include past returns and price levels in these specifications. For tests of the frequency of splits and their combined effect on prices, on the other hand, we include all listed firms.

\section{B. $\quad$ Main hypotheses}

When testing these four equations we are particularly interested in the effect of elements of $\mathbf{x}$ that proxy for catering incentives. In particular, when the relative valuations of low-priced or small-cap firms are high, relative to other firms, catering implies that prices in (4) and (7) will be lower, all else equal. With respect to equations (5) and (6), we hypothesize that when the relative valuations of low-priced or small-cap firms are high, relative to other firms, splits will be more common and lead, on average, to greater reductions in share prices.

The last hypothesis we test is complementary but somewhat distinct. We consider future returns on low-priced and small-cap firms (relative to other firms) as a dependent variable, putting split frequency $s$ and post-split prices $p$ on the right-hand side as predictors. The idea is that if mispricing indeed causes splits toward a particular price range, we may observe return predictability on stocks in that price range as their mispricing subsequently corrects.

\section{Time-series tests}

We begin with time-series tests involving average or aggregate measures of active nominal price management such as average post-split stock prices, average prices chosen by 
newly-public firms, and aggregate split frequencies of listed firms. This is a natural level of analysis because our proxies for catering incentives are purely time-series measures.

\section{A. Data on splitting activity and post-split prices}

We track stock splits and post-split prices for all shares on CRSP between 1963 through 2006 that have share codes of 10 or 11 . Stock splits are events with a CRSP distribution code of 5523. We distinguish three types of splits. Regular splits are defined as events having a split ratio of greater than 1.25-for-1. Stock dividends have split ratios between 1.01-for-1 and 1.25-for-1. Reverse splits have split ratios less than 1-for-1.

The first several columns of Table 1 report the total number of splits, the average presplit price, the average post-split price for splitters, and the aggregate effect of active price management (which we label $m$ ). The pre-split price is the closing price on the day prior to the split. The post-split price is the pre-split price divided by the split ratio. The broader measure of splitting activity $m$ measures the average active management of price over the course of the year. It is the average across all listed firms of the log difference between the actual stock price and the beginning of year stock price grown at the stock return excluding dividends. For example, in 1963 , the average is $-4.00 \%$, meaning that the average firm reduced its price by $4 \%$ through splitting activity. The last two columns show the average first-day and offering prices for IPOs. We thank Jay Ritter for providing IPO dates and offer prices; the first-day prices are from CRSP.

A salient feature of Table 1 is that the fraction of firms that splits varies considerably over time. In 1970, for example, 40 firms conduct proper splits, or fewer than two percent of listed firms, while in 1983, 780 firms split, or well over ten percent of listed firms. (A detail here is that Table 1 counts the number of splits, not the number of firms that split. However, it is rare for a firm to split more than once in a year, so the number of splits is close to the number of 
firms that split.) The broader measure of active price management also varies over time, from a maximum reduction in price of $8.69 \%$ in 1981 to an increase in price of $0.32 \%$ in 2001 . To some extent these series are driven by returns. When past returns are high, managers tend to move prices down toward their historical mean.

The "target" prices to which splitters split and the prices at which newly public firms choose to list also vary greatly over time. Shedding light on these target prices is our primary goal. At the height of the Internet bubble, the average post-split price approached $\$ 50$ per share, whereas in earlier years it had been as low as $\$ 18$. IPO prices follow a very similar pattern to average post-split prices, at lower levels. The correlation between the average post-split price and the first-day IPO price is 0.92 , while the correlation with the offering IPO price is slightly lower at 0.70 . The average post-split price is tied to variation in the average pre-split price, although of course firms can decide both when they want to split and, by manipulating the split ratio, the exact price they split to.

Finally, Table 1 shows that reverse splits are quite rare for much of the sample, and the pre- and post-split prices suggest that when they do occur they reflect an effort to satisfy exchange listing requirements, i.e. to bump prices above $\$ 5$ per share. For these reasons we give more attention to proper splits and stock dividends in the analysis.

\section{B. Data on catering incentives}

Next we form proxies for catering incentives. These are the aggregate determinants of price management $\mathbf{x}$ of most interest to us. Baker and Wurgler $(2004 a, b)$ construct a dividend premium variable based on the difference between the average valuation ratios of dividend payers and nonpayers. Similarly, we construct variables intended to capture any small-cap premia and low-nominal-price premia that may emerge in market prices. 
For starters, Figure 2A plots share price breakpoints for low- and high-priced shares. Low-priced stocks are taken to be those with per-share prices below the $30^{\text {th }}$ percentile of NYSE common stocks. High-priced stocks are those with per-share prices above the $70^{\text {th }}$ percentile. Average share prices for high-priced stocks have varied over time from a high near $\$ 50$ per share in the late 1960s to a low below $\$ 20$ per share in the early 1970s. Figure 2B plots average share prices for large-cap and small-cap firms. ${ }^{5}$ Small caps are defined as those with capitalizations below the $30^{\text {th }}$ percentile of NYSE common stocks and large caps have capitalizations above the $70^{\text {th }}$ percentile. As noted by prior authors, for example, Benartzi et al. (2007), capitalization and share prices have a very strong cross-sectional relationship, with smaller stocks typically having lower share prices.

These fluctuating share prices are associated with fluctuating valuation ratios. Figure 3A plots the average market-to-book ratios of low- and high-price stocks. Market equity is end of year stock price times shares outstanding (Compustat item 24 times item 25). Book equity is stockholders' equity (216) [or first available of common equity (60) plus preferred stock par value (130) or book assets (6) minus liabilities (181)] minus preferred stock liquidating value (10) [or first available of redemption value (56) or par value (130)] plus balance sheet deferred taxes and investment tax credit (35) if available and minus post retirement assets (330) if available. The market-to-book ratio is then book assets minus book equity plus market equity all divided by book assets. Similarly, Figure 3B plots the average market-to-book ratios of smallcap and large-cap stocks. We show the value-weighted average market-to-book ratios in these figures but we also compute equal-weighted averages. ${ }^{6}$ Both series are shown in Table 2.

\footnotetext{
${ }^{5}$ Like Bernartzi et al. (2007), we exclude Berkshire Hathaway from computations of mean prices.

${ }^{6}$ In computing the equal-weighted averages, we winsorize the market-to-book ratio of individual firms at a maximum value of 10 .
} 
Because of the strong cross-sectional relationship between size and share price, Figures $3 \mathrm{~A}$ and 3B look quite similar.

Finally, we translate these valuations into proxies for catering incentives. Figure $3 \mathrm{C}$ displays the low-price premium $P^{C M E}$ ("cheap minus expensive"), which is the log of the average market-to-book ratio of low-priced stocks minus the log of the average market-to-book of highpriced stocks. It also shows the small cap premium $P^{S M B}$ ("small minus big"), which is the $\log$ of the average market-to-book ratio of small-caps minus the log of the average market-to-book of large-caps. Again, we plot only the value-weighted average measure, but Table 2 also reports the equal-weighted measure.

Capitalization is positively correlated with the market-to-book ratio, so it is not surprising that low-priced and small stocks have on average sold at a discount in terms of their valueweighted average valuation ratios, with 1983 the lone exception in the value-weighted series. In the equal-weighted average valuation ratios, small stocks displayed a premium valuation ratio from 1979 through 1985 and in 2003 and 2004. More importantly for this analysis, the equalweighted premium for high-priced stocks has very similar variation.

Historical market commentaries give some color to the peaks and troughs in the lowprice and small-cap premia. For example, according to Malkiel (1999), two peaks in Figure 3C, the late-1960s and 1983, were both notable eras for new issues, which tended to be low-price and of small capitalization. There are also two troughs in which large caps and high-priced stocks were apparently more in favor. One is the early 1970s and reflects what Siegel (1998) calls the "nifty fifty" bubble. The name refers to fifty large, stable, consistently profitable stocks. Siegel writes, "All of these stocks had proven growth records ... and high market capitalization" and surely high nominal share prices (p. 106). Another trough occurs in the Internet period. This is 
driven by extraordinary valuations on high-price, large-cap stocks, consistent with the popular impression of a long bull market for the S\&P 500 that started in the 1980s. It also reflects the valuations of many growth stocks that had such high returns that they quickly leapfrogged smaller capitalization firms to become high-price, large-cap stocks. Indeed, data from Jay Ritter's website indicate that the average first-day return among the 1999 IPO cohort was $70 \%$.

Two historical anecdotes seem particularly à propos of the catering hypothesis. Malkiel describes the proposed offering of Muhammad Ali Arcades International in 1983, at the very peak of the small-stock and low-price premium in Figure 3C. The firm proposed to offer units of one share plus two warrants at the price of one penny. "... when it was discovered that the champ himself had resisted the temptation to buy any stock in his namesake company, investors began to take a good look at where they were. Most did not like what they saw. The result was a dramatic decline in small company stocks in general" (1999, p. 77-78). As a second interesting anecdote, in 1989, at the tail end of a 15-year period of outperformance of low-price stocks, Fidelity Investments launched the Low-Priced Stock Fund. The fund's mandate was to select stocks trading at $\$ 10$ or less. Over the next several years-as high-price stocks began to outperform - the definition of "Low-Priced" was reset to $\$ 25$ and then to $\$ 35$.

In addition to relative valuation ratios, we also use the market reaction to splits as a proxy for catering incentives. When splitting firms are greeted with a positive market reaction (Fama, Fisher, Jensen, and Roll (1969) and subsequent authors find that the average split announcement is positive) perhaps the simplest inference is that investors prefer lower prices. More specific evidence comes from Greenwood (2007b), who shows that Japanese firms split more frequently following high split announcement effects. He also finds that high split announcement effects are associated with higher split ratios. Both results are consistent with catering. Of course, at least in 
the U.S., positive news about earnings or dividends news is often announced at the same time as a split. In using the market reaction to splits as a measure of catering incentives, we are implicitly assuming that this news content is similar across years or, to the extent it varies over time, that it is not correlated with catering incentives.

Specifically, we compute the return in the window from the day before the CRSP split announcement date through 10 days after the effective date, net of the value-weighted market index. $^{7}$ To control for differences in volatility across firms and across time (see Campbell, Lettau, Malkiel and Xu (2000)), we scale each firm's excess return by the square root of the number of days in the window times the standard deviation of its daily excess returns. We measure volatility in the period from 100 days prior to the split announcement through five days before the announcement. We label the standardized announcement effect $A$ and report the average within each year over time. This series is presented in Table and in Panel D of Figure 3. The figure shows that $A$ varies considerably over time, from a high of 0.88 in 1977 , meaning that the average event return was 0.88 standard deviations above zero, to a low of 0.13 in 1962 . The figure also shows a fairly high degree of correlation between $A$ and the low price $(\rho=45 \%)$ and small cap premia $(\rho=52 \%)$. Thus, the valuation benefits of splitting vary with our premium measures in an intuitive way. We view all of these measures as alternative, but noisy proxies for catering incentives.

\section{C. $\quad$ Catering incentives and splitting activity}

We start by examining whether aggregate measures of split activity, as in equations (5) and (6), is related to measures of catering incentives. Specifically, we regress the split percentage and the broader measure of splitting activity on equal- and value-weighted measures of the low

\footnotetext{
${ }^{7}$ We have experimented with different windows for measuring the announcement premium, achieving similar results using both shorter and longer windows. We also find that the announcement premium is not much affected whether one includes or excludes split dividends in the calculation of $A$.
} 
price and small stock premia and the split announcement premium, controlling for beginning of period prices and returns:

$$
\begin{aligned}
& s_{t}=a+b P_{t-1}^{C M E}+c P_{t-1}^{S M B}+d A_{t-1}+e p_{t-1}^{E W}+f r_{t}^{E W}+u_{t}, \text { and } \\
& m_{t}=a+b P_{t-1}^{C M E}+c P_{t-1}^{S M B}+d A_{t-1}+e p_{t-1}^{E W}+f r_{t}^{E W}+u_{t} .
\end{aligned}
$$

We expect the low price and small stock premia, labeled $b$ and $c$, as well as the split announcement effect, labeled $d$, to have a positive relationship to the split percentage. In other words, when low priced and small stocks are trading at a premium relative to high priced and large stocks, or when splits are associated with larger announcement returns, we expect to see more firms splitting their shares down to lower prices, in the hopes of attracting investor demand. The broader measure of splitting activity is decreasing in the propensity to split and the split ratio, so we expect opposite signs, i.e., when low priced and small stocks are trading at a premium. Or, once again, when splits are associated with high announcement returns, we expect to see firms taking actions $m$ to decrease their stock prices. Note in the measure $s$ we include both splits and stock dividends; it makes little difference if we exclude stock dividends. The measure $m$ includes all firms and thus is the net effect of splits of any type.

The estimates of $b, c$, and $d$ in Table 4 are broadly consistent with these predictions. The top panel shows univariate results. All ten coefficients have the correct sign, and all but two are statistically significant at the five percent level. Standard errors are adjusted for heteroskedasticity and autocorrelation of up to three lags and all of the independent variables are standardized. Thus, in terms of economic significance, a one standard deviation increase in the value-weighted low-price premium, for example, is associated with a 0.94 percentage point increase in split frequency and a 0.85 percentage point net decrease in prices through active price management. Equal-weighting the low price premium or using the small stock premium as a 
measure of catering incentives leads to slightly larger effects. Split announcement effects are associated with split frequencies as well as being strongly associated with net decreases in prices.

The bottom panel shows multivariate results that control for the overall equal-weighted average share price from the beginning of the year and the equal-weighted average return over the course of the year. Naturally, split activity is more common when share prices and returns are generally high. More important for us is that the inclusion of these control variables does not affect the coefficients on catering proxies, which are similarly strong. In fact, the t-statistics on catering incentives are typically as high as the t-statistics on the average price level (unreported), and the inclusion of these variables does not greatly increase goodness of fit relative to univariate regressions that contain only catering incentives. One might have expected the average price level to be the dominant effect on overall split activity, but these results suggest that catering incentives may be as important.

\section{Catering incentives and IPO and post-split prices}

Next we examine IPO and post-split prices, as in equations (4) and (7). These are situations where the firm has explicitly chosen a stock price. Catering predicts that splitters will split to lower prices and new firms will list with higher prices when low-priced firms (or small firms) are more highly valued. In some respects, this is a clearer test. We expect to see more splitting activity simply in response to higher prices and past returns, but we would not necessarily expect to see differences in post split or IPO prices.

Figure 4 shows the relationship between catering incentives and IPO first-day closing prices. Initial public offerings offer a unique setting to test for catering effects on prices, as the price is highly discretionary, there are strong incentives to adapt cosmetic aspects of the firm to attract investor demand, and there is no issue of inertia with respect to a particular historical 
price range. Average IPO closing prices almost tripled from 1984 to 1999 and have fallen more recently. This variation appears to be well explained by proxies for catering incentives, which are inverted and once-lagged in the figure. The figure shows that when the relative valuations of large or high-priced stocks are high, firms go public at higher prices, and vice-versa. The correlation between IPO closing prices and the lagged value-weighted low price premium is 0.88 and the correlation with the small stock premium is -0.84 .

Perhaps the central result of the paper is illustrated in Figure 5, which looks at the larger and longer sample of post-split prices chosen by seasoned firms. The average post-split price is plotted against the low price and small stock premia, lagged one period and inverted. The variation in post-split prices is qualitatively similar to the variation in prices chosen by newlypublic firms. In 2000 , for example, the average post-split price was nearly $\$ 50$, or more than double the average price that firms had been splitting to just a few years earlier and roughly double the price that firms would be splitting to a few years later. Measures of catering incentives again appear to help explain this variation. When the low-price premium is relatively high, firms that conduct splits split to lower prices. The correlation between the post-split price and the value-weighted low price premium is -0.72 . The correlation with the small stock premium is -0.64 . The 2000 spike in post-split prices matches a spike in the relative valuation of small-cap and low-price firms, but there seems to be a correlation in other periods as well.

Somewhat more formally, we regress IPO and post-split prices on equal- and valueweighted versions of the low price and small stock premium and the split announcement premium, controlling for beginning of period prices and returns:

$$
\begin{aligned}
& p_{t}^{I P O}=a+b P_{t-1}^{C M E}+c P_{t-1}^{S M B}+d A_{t-1}+e p_{t-1}^{E W}+f r_{t}^{E W}+u_{t}, \text { and } \\
& p_{t}=a+b P_{t-1}^{C M E}+c P_{t-1}^{S M B}+d A_{t-1}+e p_{t-1}^{E W}+f r_{t}^{E W}+u_{t} .
\end{aligned}
$$


We expect that $b, c$, and $d$ on actively chosen prices to be negative. In other words, when low priced and small stocks are trading at a premium relative to low priced and small stocks, or when splits to lower prices are associated with a larger announcement effect, we expect to see firms choosing lower prices. ${ }^{8}$

The estimates in Table 5 are consistent with predictions. The top panel shows univariate results, and the bottom panel controls for past prices and contemporaneous returns. Of the twenty coefficients, all have the right sign and all but one are significant at the five percent level. In terms of economic significance, a one-standard-deviation increase in the low-price premium is associated with a 19 percentage-point decrease in IPO prices and a 17 percentage-point decrease in post-split prices. Results for the small-stock premium are similarly strong. These effects are only slightly affected by the inclusion of average prices and recent returns as control variables, and the inclusion of such controls increases the statistical and economic significance of the split announcement premium.

\section{E. Robustness checks}

We test several aspects of the robustness of the link between catering incentives and postsplit prices. The first row of Table 6 repeats as a base case the multivariate results for valueweighted measures of catering incentives from Table 5.

We start by examining whether the results come predominantly from one part of the sample. Splitting the sample into halves indicates that this is not the case. A second concern is that both the premia and the average post split price may share a common time trend, leading to a spurious correlation. The fourth row shows that controlling for a time trend only strengthens the results. In the fifth row, we go a step further and run equation (9) in differences, removing the

\footnotetext{
${ }^{8}$ We use log prices as dependent variables here, but we obtain similar results using dollar prices.
} 
time trend from both series. Thus, the dependent variable is the change in the log post-split price, and the independent variable is the lagged change in the low-price (or small-cap) premium. Again, results are similar. Related to the difference specification, we estimate GLS specifications based on a variant of the Cochrane-Orcutt procedure, which assumes that regression residuals are AR(1). Again, the results are similar and significant. Finally, in untabulated results we find that the level of the log post-split price is significantly related to past changes in the low-price (or small-cap) premium.

The sixth row uses the past relative returns of cheap and expensive stocks and small and large stocks. We compound these differences over the three years prior to year $t$ and use the gap in returns to predict the average post split price in year $t$. As expected, the basic results are qualitatively unchanged. In the seventh row we replace IPO first-day closing prices with offering prices. Although Loughran and Ritter (2002) show that the closing price is predictable, the offering price may be a better gauge of the intended share price. In any event, the results are not sensitive to this distinction, though the coefficient increases as a result of the lower variance of offering prices.

Another conceivable issue with the results in Table 5 involves a composition effect. Suppose that small firms always split to low prices and large firms always split to higher prices. Then, when small-cap or low-price premia are high, we would expect more small firms to be potential splitters. Since small firms split to lower prices, the average post-split price will be lower, potentially producing the effect in Table 5 . An easy test of this alternative explanation is to separate small from large firms. We define small firms as those with market capitalization less than the $30^{\text {th }}$ NYSE percentile and large firms as those with market cap greater than the $70^{\text {th }}$ percentile. The eighth and ninth rows of the robustness table show that the results are driven by 
large firms. Thus, the results appear to reflect large firms trying to "act small" (when catering incentives point in that direction) rather than the composition effect suggested above. Perhaps smaller listed firms have less scope to alter investor perceptions, especially if their prices are already low (reverse splits are rare as shown in Figure 1). At the same time, the results for IPO prices involve smaller and younger firms, and so catering incentives may be important at different stages of the firm life cycle.

The final two rows represent a single regression result. We split the low price and small stock premia into their components. This addresses a class of alternative explanations in which our catering incentives measures are correlated with overall valuation levels. For example, high overall valuation levels may proxy for low expected returns, so perhaps firms choose not to split to low prices because they expect their price to fall on its own. A simple test is to see whether the effect is coming from both or just one part of our relative valuation measures. The results suggest that post-split prices are significantly positively related to the valuations of high priced (or large) stocks as well as significantly negatively related to the valuations of low priced (or small) stocks.

A class of explanations that is popular in the splits literature involves signaling. It is hard to rule out signaling as an explanation for any particular split or pattern of a firm's decisions. For example, Applied Materials may have split to lower prices because of increased confidence that its current valuation was not too high. However, signaling is unlikely to explain our large sample results. We find a pattern between a publicly available data (the relative valuation of low and high priced firms) and the propensity to split. While this could reflect time series variation in asymmetric information, it would more naturally predict that the need to signal was greater, not lesser, when low priced and small stocks (opaque firms) were trading at a discount. 


\section{Firm-level tests}

As another robustness test we can use firm-level data. This allows us to more fully control for composition effects that could affect average post-split prices and split activity but that do not involve catering, as well as to correct for effects related to variation over time in the cross-sectional dispersion in prices or other relevant characteristics. The specific approach is to add time series measures of catering incentives to pooled firm level regressions corresponding to eqs. (4) through (7).

\section{A. Data}

We gather firm- and industry-level determinants of splits and post-split share prices at an annual frequency. We take beginning-of-year nominal share prices and construct annual stock returns using CRSP data. We measure firm size as the NYSE capitalization decile as of the end of the previous calendar year. We control for industry average prices using Fama and French (1997) industry classifications. In some cases we also control for idiosyncratic, firm-specific preferences for a specific price range by using the price to which the firm split when it split the last time (whether that was a proper split, a stock dividend, or a reverse split). Inclusion of this last control limits the sample to firms that have split previously.

\section{B. $\quad$ Catering incentives and firm-level splitting activity}

In Table 7, we estimate the firm level analogue to our time series regressions in Table 4. An indicator variable equal to one when firms $i$ splits or pays a stock dividend in quarter $t$ replaces the aggregate split percentage, and the firm level measure of the net impact of splitting activity $m$ replaces the equal weighted average across firms. We regress these dependent variables on the value-weighted low price premium, controlling for beginning of period prices $p$,

contemporaneous returns $r$, the NYSE size decile NYSED, the industry average price $p^{\text {Industry }}$, and 


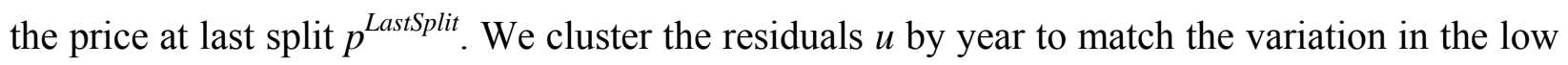
price premium. $^{9}$

$$
\begin{aligned}
& \operatorname{Pr}\left(s_{i, t}=1\right)=a+b P_{t-1}^{C M E}+e p_{i, t-1}+f r_{i, t}+g N Y S E D_{i, t}+h p_{i, t-1}^{\text {Industry }}+j p_{i, t-1}^{\text {LastSplit }}+u_{i, t}, \text { and } \\
& m_{i, t}=p_{i, t}-p_{i, t-1}-r_{i, t}=a+b P_{t-1}^{C M E}+e p_{i, t-1}+f r_{i, t}+g N Y S E D_{i, t}+j p_{i, t-1}^{\text {Industry }}+h p_{i, t-1}^{\text {LastSplit }}+u_{i, t} .
\end{aligned}
$$

As before, we expect the coefficient on the low price premium $b$ to have a positive sign in the first equation and a negative sign in the second. We expect the effect of past price and contemporaneous returns to be positive for splits and negative for the broader measure $m$. That is, when prices are high initially or because of recent returns, we expect to see more splits and more downward management of price. Firms in size deciles and industries with higher prices are likely to split less and manage prices higher. Finally, firms may have their own idiosyncratic preference for share price that is manifested in past stock splits. Those with preferences for low prices will split more often and manage price downward.

These predictions are supported in Table 7. Splits are more common when prices are higher, when returns are higher, when the industry average share price is lower (as in Lakonishok and Lev (1987), and when the firm's last post-split price is lower. Large firms are somewhat less likely to split, all else equal, consistent with the cross-sectional pattern in which large firms maintain higher average share prices. More importantly, the high price premium has the correct sign in all six regressions, and is significant at the five percent level in five out of six. In the first specification in the top panel, a one-standard deviation increase in the low price premium is associated with a 0.50 percentage point increase in the probability that a firm will split in that year, all else equal. This may appear small but it should be compared to the

\footnotetext{
${ }^{9}$ We have also estimated t-statistics following Thompson (2006), who describes a technique for obtaining standard errors when residuals are clustered both by firm and in time. Although this adjustment appears to matter for many of the control variables, it does not much affect the significance of $b$, the coefficient on the low price premium.
} 
unconditional probability of a split in a given year, which is roughly four to twelve percentage points, as can be inferred from Table 1. Note also that we are controlling for beginning of year price, which itself reflects the impact of our annual proxy for catering incentives. It is also associated with a 0.79 percentage point reduction in the average firm's share price that year as effected through splitting activity.

\section{Catering incentives and firm-level IPO and post-split prices}

In Table 8, we estimate the firm level analogue to the time series regressions in Table 5. Firm level IPO prices and post-split month-end prices replace the time series averages. We regress these dependent variables on the value-weighted low price premium, controlling for the $\log$ price following the last split $p^{\text {LastSplit }}$ and returns since the last split $r^{\text {LastSplit }}$ in the case of postsplit prices, the NYSE size decile NYSED, and the industry average price $p^{\text {Industry }}$.

$$
\begin{aligned}
& p_{i, t}^{\text {IPO }}=a+b P_{t-1}^{C M E}+g N Y S E D_{i, t}+h p_{i, t-1}^{\text {Industry }}+u_{i, t} \\
& p_{i, t}=a+b P_{t-1}^{C M E}+c p_{i, t-1}^{\text {Lastsplit }}+d r_{i, t}^{\text {Lassplit }}+e N Y S E D_{i, t}+f p_{i, t-1}^{\text {Industry }}+u_{i, t}
\end{aligned}
$$

For firms that have not split before, $p^{\text {LastSplit }}$ denotes the log month-end price following the IPO, and $r^{\text {LastSplit }}$ is the log ex-dividend return since the IPO.

Here, we expect the coefficient on the low price premium $b$ to be negative, as before, and all other coefficients to be positive. These predictions are borne out in Table 8. Notably, the low price premium is negative in all four regressions and statistically significant at the five percent level in three of them. The base case result for post-split prices implies that a one-standard deviation increase in the low-price premium is associated with firm-level prices that are on average lower by about 5 percentage points, all else equal.

The results for IPOs are statistically somewhat weaker, although they are economically larger, with a one-standard deviation increase in the low-price premium associated with a three 
to four percentage point decrease in IPO prices. This lower statistical significance is partly a function of the smaller sample but primarily due to the size control. Without the size control, the coefficient $b$ is -0.17 with a t-statistic of -8.41 . This suggests that firms that are small (relative to existing NYSE stocks) are much more likely to go public when the low price and small stock premium are high. This is broadly consistent with the notion that investor demand for small and low priced stocks varies over time. One way to satiate this demand is to split; the other is to bring more firms with these characteristics public.

We have also tried an alternative estimation approach. In analogy to Fama and French (2001) and Baker and Wurgler (2004b), who estimate the "propensity to pay dividends," we also estimate the firm-level "propensity to split" as a function of firm- and industry-specific factors, in the first stage, and ask whether catering incentives help to explain the remaining time variation (the constant term in the cross-sectional regressions), in the second stage. Similarly, we estimate the firm-level "active price manipulation due to splits" as a function of firm- and industryspecific factors, and ask whether unexplained time fixed effects depend on prevailing catering incentives. This procedure has the benefit of giving equal weight to each time period, but has disadvantages. The effect of the time series predictor in the second stage can be contaminated by the first stage variables. In particular, the time series averages of the firm-level predictors can make up an important part of the variation in the annual average residuals. Whatever the relative merits, it is comforting that this procedure produces similar results to the pooled regressions shown here, so we omit the results.

\section{Future stock returns}


In the purest catering theory, firms split in an effort to categorize themselves, via their new share price, into a group of small or low-price firms that is relatively overvalued. If this is accurate, then split activity may forecast the returns on small or low-priced stocks, relative to the returns on large or high-priced stocks, as prices eventually revert. On the other hand, it is also possible that the catering activity is misguided, and no actual misvaluation exists, i.e. small and low-price firms have high valuations because their fundamentals are strong. Still another possibility is that misvaluation exists, but because corrections of mispricing are irregular they may go undetected in predictive regressions with relatively short time series.

We consider two of the time series we have focused on, the frequency of splits and average post-split share prices, as potential forecasters of the SMB and CME relative return factors. Also, since the equal-weighted average nominal price level itself has such a strong effect on the frequency of splits and average post-split share prices, we control for it. In other words, we ask whether "excess" splitting activity, or "excess" variation in post-split prices, predicts returns. The predictive regressions are

$$
\begin{aligned}
& R_{t+1}=a+b s_{t}+c p_{t-1}^{E W}+u_{t} \\
& R_{t+1}=a+b p_{t}+c p_{t-1}^{E W}+u_{t}
\end{aligned}
$$

where $R$ denotes the return on low minus high priced stocks or small minus large cap stocks. We consider forecasts of one-, two-, and three-year ahead relative returns.

As it turns out, the results in Table 9 are quite supportive of catering. The left columns show that when splits are particularly frequent, controlling for overall average share prices, future returns are lower on low-price stocks relative to high-price stocks, and on small-cap stocks relative to large-cap stocks. For example, suppose the aggregate frequency of splits increases by one percentage point, which is about a third of its standard deviation. Then, controlling for 
overall average share prices, equal-weighted returns on low-priced stocks are lower, relative to equal-weighted returns on high-priced stocks, by a total of 8.27 percentage points over the next three years. This is in the direction consistent with splits as a response to ex ante relative overvaluation of low-priced stocks and the magnitude seems substantial.

The right columns show that average post-split share prices are also useful for predicting size- and price-based relative return factors. Suppose that average post split prices are lower by one nominal dollar, which is about a sixth of one standard deviation. Then, controlling for overall average share prices, for example, the equal-weighted returns on low-priced stocks are low relative to the returns on high-priced stocks by a total of 3.45 percentage points over the next three years. Again, this magnitude seems nontrivial and the direction is consistent with ex ante relative overvaluation of low-priced stocks inspiring splitters to target lower prices. ${ }^{10}$ And we note that, in addition to being nicely consistent with the catering hypothesis, this evidence of return predictability further casts doubt on rational expectations versions of signaling.

\section{Conclusion}

Boards of directors are free to choose whatever nominal price they decide is optimal, subject only to listing requirements. Existing theories of nominal share prices typically invoke frictions such as trading costs and asymmetric information. In this paper, we suggest a catering theory of nominal share prices in which firms manage share prices toward the price range that

\footnotetext{
${ }^{10}$ Stambaugh (1999) describes the potential for bias due to autocorrelated regressors whose innovations are correlated with returns. Annual innovations in stock splits and post split prices are not statistically correlated with relative returns of high- and low-priced stocks or small and large stocks. The correlations range from -0.04 to -0.17 for stock splits (the wrong sign for bias) and from -0.02 to -0.16 for post split prices (correct sign but small magnitudes). Moreever, the reduced-bias estimator of Amihud and Hurvich (2004) indicates virtually no bias for either predictor in our setting. However, standard errors using the Amihud-Hurvich approach are slightly above those in Table 9. The difference comes primarily from switching from the homoskedastic to robust standard errors, not from the bias correction.
} 
investors currently prefer. The "friction" in the catering theory is limits to arbitrage that allow for mispricing based on nominal share price levels.

We find several elements of empirical support for a catering view of share prices. Splits are far more common, and to lower prices, when the valuation ratios of small- and low-priced firms are high relative to the valuation ratios of large- and high-priced firms. Simple valuation ratio-based proxies of catering incentives explain a large fraction of variation in post-split share prices. They explain an especially large fraction of variation in the prices chosen by newlypublic firms. Finally, consistent with active price management as an effort to take advantage of relative overvaluation of low-priced firms, split activity or splits to lower prices predicts relatively low returns on low-priced firms and small-cap firms over the next few years. 


\section{References}

Aghion, Philippe, and Jeremy Stein, 2007, Growth vs. margins: Destabilizing consequences of giving the stock market what it wants, forthcoming Journal of Finance.

Amihud, Yakov, and Clifford M. Hurvich, 2004, Predictive regressions: A reduced-bias estimation method, Journal of Financial and Quantitative Analysis 41, 637-660.

Angel, James J., 1997, Tick size, share prices, and stock splits, Journal of Finance 52, p. 655681.

Asquith, Paul, Paul Healy, and Krishna Palepu, 1989, Earnings and stock splits, The Accounting Review 64, 387-403.

Baker, H. Kent, and Patricia L. Gallagher, 1980, Management's view of stock splits, Financial Management 9, 73-77.

Baker, Malcolm, Richard Ruback, and Jeffrey Wurgler, 2007, Behavioral corporate finance: A survey, ed. Espen Eckbo, (Amsterdam: North-Holland).

Baker, Malcolm, and Jeffrey Wurgler, 2004a, A catering theory of dividends, Journal of Finance $59,1125-1165$.

Baker, Malcolm, and Jeffrey Wurgler, 2004b, Appearing and disappearing dividends: The link to catering incentives, Journal of Financial Economics 73, 271-288.

Barber, Brad, and Terrence Odean, 2007, All that glitters: The effect of attention and news on the buying behavior of individual and institutional investors, Review of Financial Studies, forthcoming.

Barberis, Nicholas, Andrei Shleifer, and Jeffrey Wurgler, 2005, Comovement, Journal of Financial Economics 75, 283-318.

Benartzi, Shlomo, Roni Michaely, Richard H. Thaler, and William C. Weld, 2007, The nominal price puzzle, UCLA working paper.

Bikhchandani, Sushil, David Hirshleifer, and Ivo Welch, 1992, A theory of fads, fashion, custom, and cultural change as informational cascades, Journal of Political Economy 100, 992-1026.

Black, Fischer, 1986, Noise, Journal of Finance 41, 529-543.

Brennan, Michael, and Thomas Copeland, 1988, Stock splits, stock prices, and transactions costs, Journal of Financial Economics 22, 83-101.

Campbell, John Y., Martin Lettau, Burton G. Malkiel, and Yexiao Xu, 2001, Have individual stocks become more volatile? An empirical exploration of idiosyncratic risk, Journal of Finance 56, 1-44. 
Cooper, Michael J., Orlin Dimitrov, and P. Raghavendra Rau, 2001, A rose.com by any other name, Journal of Finance 56, 2371-2388.

Cooper, Michael J., Ajay Korana, Igor Osobov, Ajay Patel, and P. Raghavendra Rau, 2004, Managerial actions in response to a market downturn: Valuation effects of name changes in the dot.com decline, Journal of Corporate Finance, forthcoming.

Dolley, James C., 1933, Common stock split-ups-Motives and effects, Harvard Business Review October, 70-81.

Dyl, Edward, and William B. Elliott, 2006, The share price puzzle, Journal of Business 79, 20452066.

Fama, Eugene F., Lawrence Fisher, Michael C. Jensen, and Richard Roll, 1969, The adjustment of stock prices to new information, International Economic Review 10, 1-21.

Fama, Eugene F., and Kenneth R. French, 1997, Industry costs of equity, Journal of Financial Economics 43, 153-193.

Fama, Eugene F., and Kenneth R. French, 2001, Disappearing dividends: Changing firm characteristics or lower propensity to pay?, Journal of Financial Economics 60, 3-44.

Hirshleifer, David, and Siew Hong Teoh, 2002, Limited attention, information disclosure, and financial reporting, Journal of Accounting and Economics 36, 337-386.

Gompers, Paul, and Andrew Metrick, 2001, Institutional ownership and equity prices, The Quarterly Journal of Economics 116, 229-259.

Green, T. Clifton, and Byoung-Hyoun Hwang, 2007, Price-based return comovement, Emory University working paper.

Greenwood, Robin, 2007a, Excess Comovement: Evidence from cross-sectional variation in Nikkei 225 weights, forthcoming Review of Financial Studies.

Greenwood, Robin, 2007b, Trading restrictions and stock prices, forthcoming Review of Financial Studies.

Greenwood, Robin, and Nathan Sosner, 2007, Trading patterns and excess comovement of stock returns, forthcoming Financial Analysts Journal.

Hong, Harrison, Jialin Yu, and Jiang Wang, 2007, Firms as buyers of last resort, Review of Financial Studies, forthcoming.

Journal of Financial Economics, forthcoming.

Lakonishok, Josef, and Baruch Lev, 1987, Stock splits and stock dividends: Why, who, and when, Journal of Finance 42, 913-932. 
Lakonishok, Josef, Robert Vishny, and Andrei Shleifer, 1992, The impact of institutional trading on stock prices, Journal of Financial Economics 32, 23-43.

Li, Wei, and Erik Lie, 2006, Dividend changes and catering incentives, Journal of Financial Economics 80, 293-308.

Loughran, Tim, and Jay R. Ritter, 2002, Why don't issuers get upset about leaving money on the table in IPOs?, Review of Financial Studies 15, 413-443.

Malkiel, Burton G., 1999, A Random Walk Down Wall Street, (Norton, New York, NY).

Merton, Robert C., 1987, A simple model of capital market equilibrium with incomplete information, Journal of Finance 42, 483-510.

Ohlson, James A., and Stephen H. Penman, 1985, Volatility increases subsequent to stock splits, Journal of Financial Economics 14, p. 251-266.

Odean, Terrence, 1999, Do investors trade too much?, American Economic Review 89, 12791298.

Polk, Christopher, and Paola Sapienza, 2006, The stock market and investment: A test of catering theory, Review of Financial Studies, forthcoming.

Siegel, Jeremy, 1998, Stocks for the Long Run, (McGraw-Hill, New York).

Stambaugh, Robert F., 1999, Predictive regressions, Journal of Financial Economics 54, 375421.

Thompson, Samuel B., 2006, "Simple Formulas for Standard Errors that Cluster by Both Firm and Time", working paper Harvard University 
Figure 1. Stock splits by Applied Materials, Inc. Applied Materials monthly share price (solid) is plotted against the low price premium (dash - scale adjusted and inverted). Applied Materials went public in the fourth quarter of 1972, split its stock for the first time in the second quarter of 1980 and eight more times through 2004. Diamonds indicate split dates and mark the post-split price.

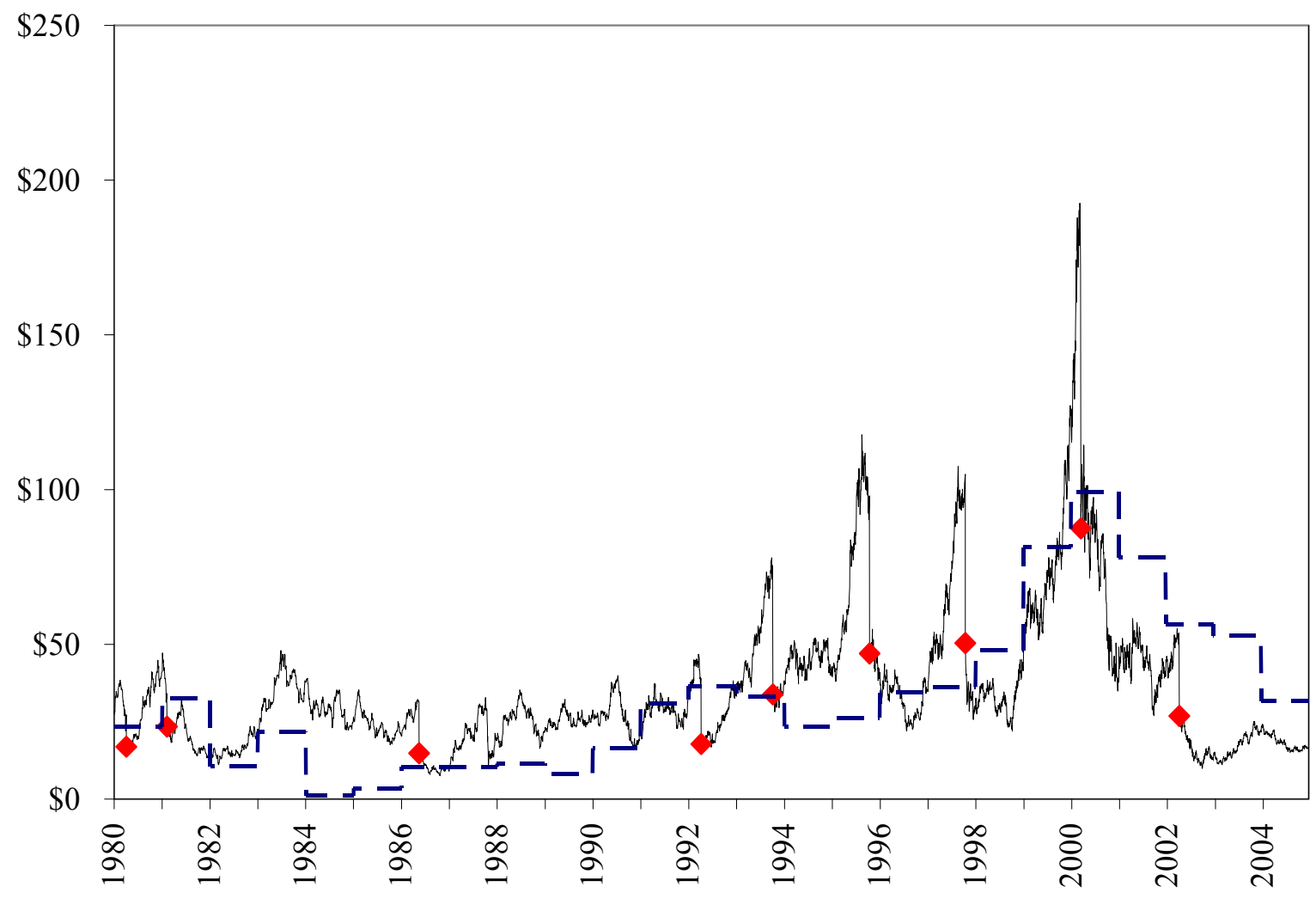


Figure 2. Share price breakpoints. In Panel A., all NYSE stocks with share codes of 10 or 11 are ranked each year by share price at the end of December. The figure shows the $30^{\text {th }}$ percentile and $70^{\text {th }}$ percentile share price breakpoints. In Panel B, all NYSE stocks with share codes of 10 or 11 are ranked each year by market capitalization at the end of December. The figure shows the equal-weighted average share price for stocks with market capitalizations below the $30^{\text {th }}$ percentile and above the $70^{\text {th }}$ percentile.

Panel A. Share price breakpoints for high-price (solid) and low-price (dash) stocks

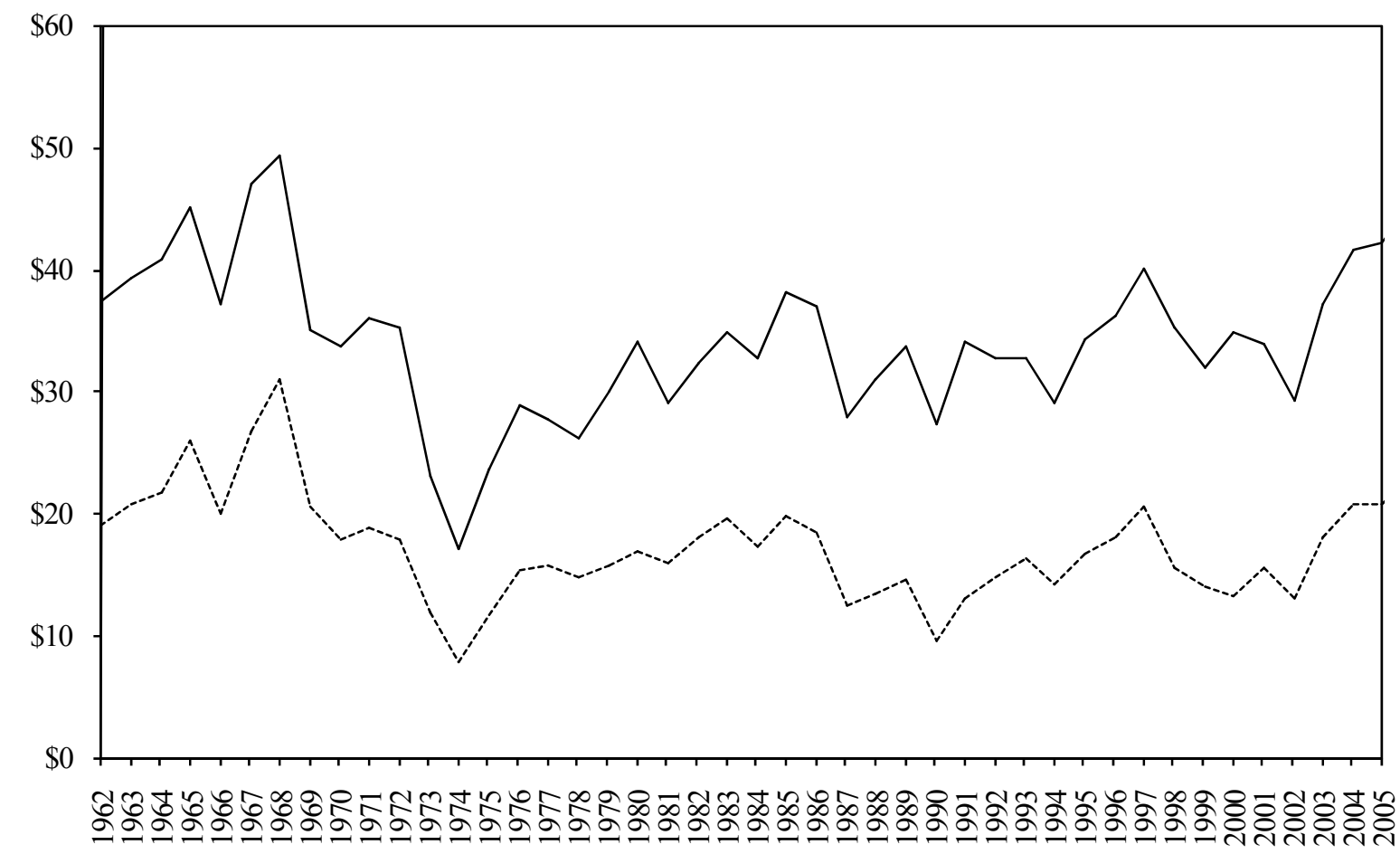

Panel B. Average share prices for large (solid) and small-cap (dash) stocks

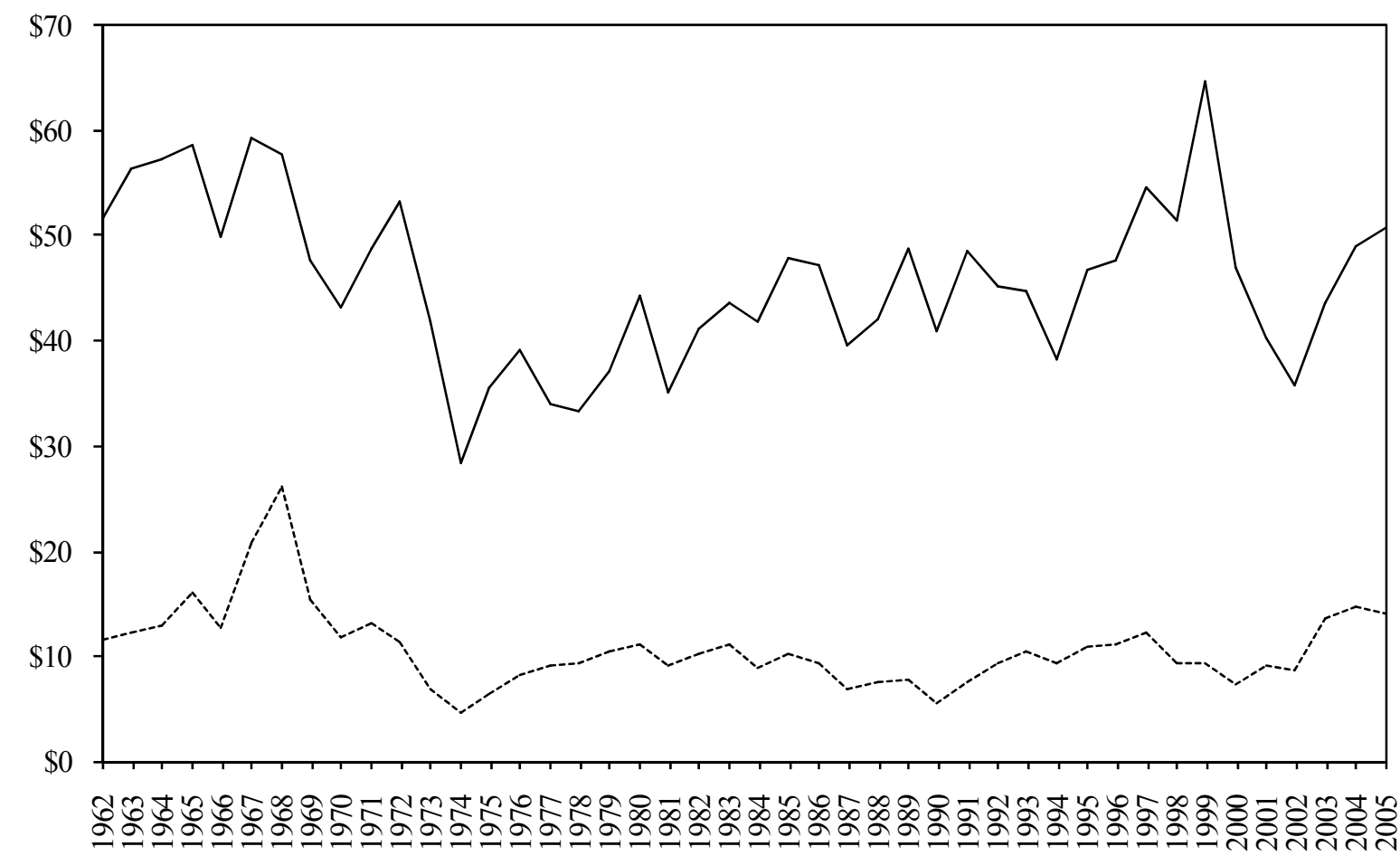


Figure 3. The low price and small stock premia, and the split announcement premium. The low price premium is the log difference in the value weighted average market-to-book ratios of low and high priced stocks. The small stock premium is the log difference in the value weighted average market-to-book ratios of small and large stocks. The market-to-book ratio is the ratio of the market value of the firm to its book value. Market value is equal to market equity at calendar year end (item 24 times item 25) plus book debt (item 6 minus book equity). Book equity is defined as stockholders' equity (generally item 216, with exceptions as noted in the text) minus preferred stock (item 10) plus deferred taxes and investment tax credits (item 35) and post retirement assets (item 330). All NYSE stocks with share codes of 10 or 11 are ranked each year by share price and market capitalization at the end of December. Low (high) price stocks are stocks with share prices below the $30^{\text {th }}$ percentile (above the $70^{\text {th }}$ percentile) by share price. Small (large) stocks are stocks with market capitalizations below the $30^{\text {th }}$ percentile (above the $70^{\text {th }}$ percentile) by capitalization. Panels A and B plot the value weighted average market-to-book ratios of high and low priced stocks and large and small stocks. Panel C plots the low price and small stock premia. Panel D plots the split announcement premium, defined as the abnormal return from the day before split announcement through ten days after the effective date, scaled by the standard deviation of returns.

Panel A. Value weighted average market-to-book ratio for high price stocks (solid) and low price stocks (dash)

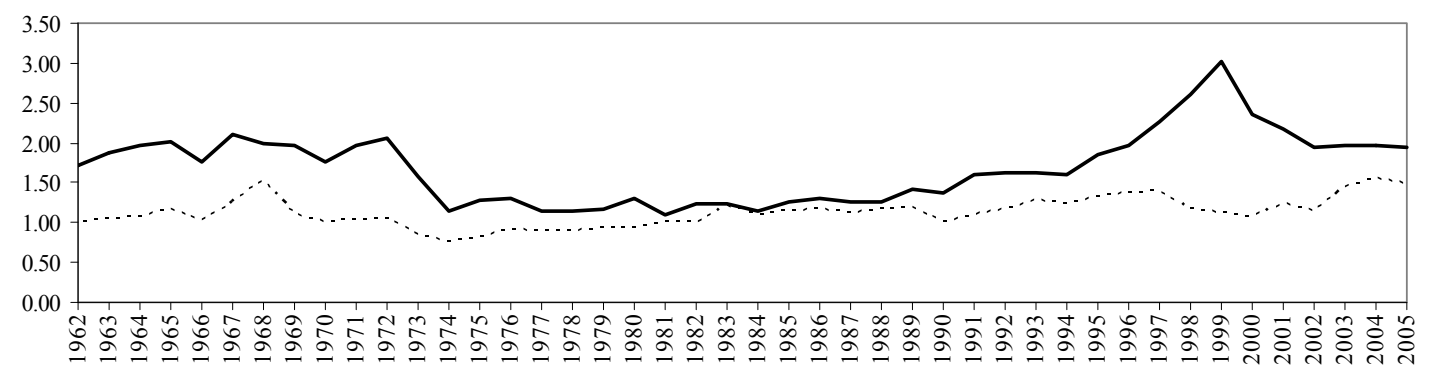

Panel B. Value weighted average market-to-book ratio of large stocks (solid) and small stocks (dash)

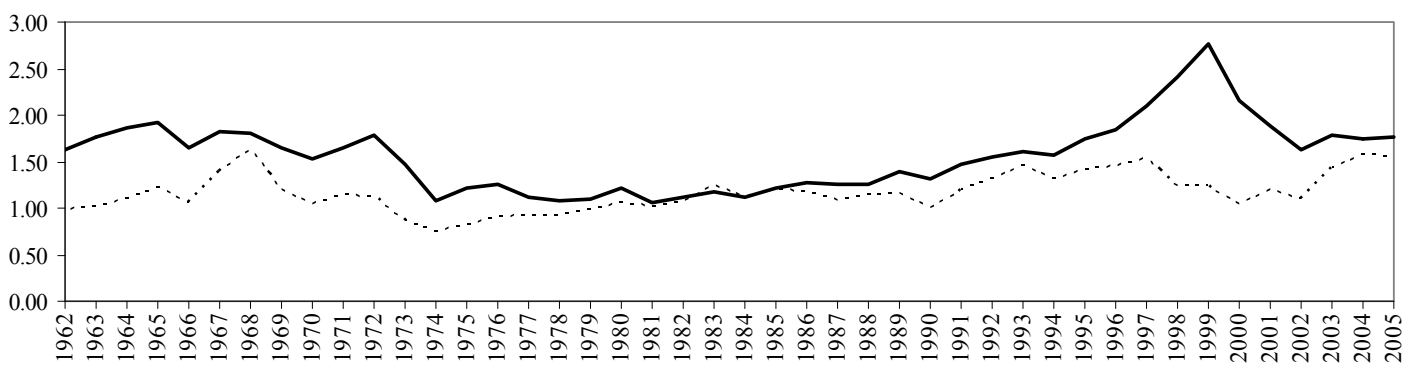

Panel C. The low price premium (solid) and small stock premium (dash)

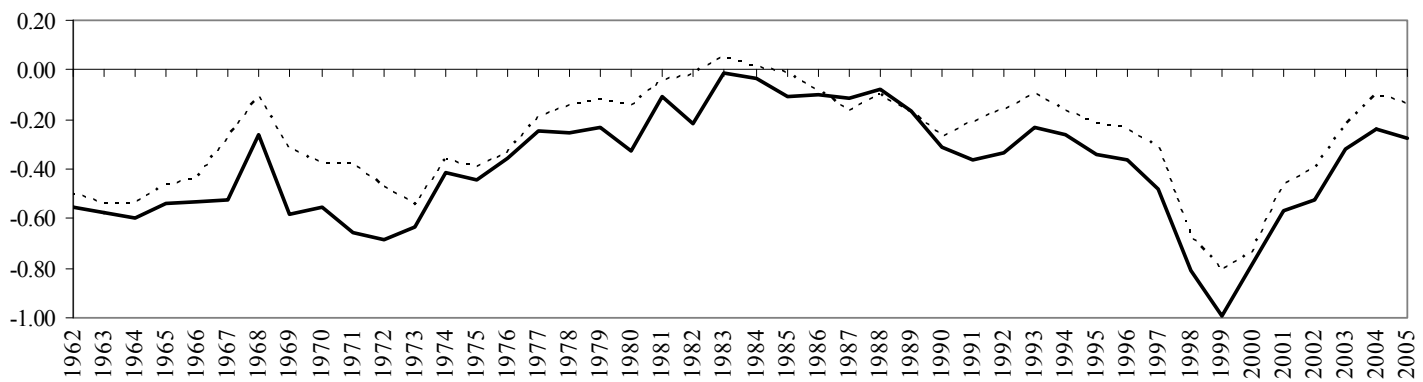

Panel D. The split announcement premium

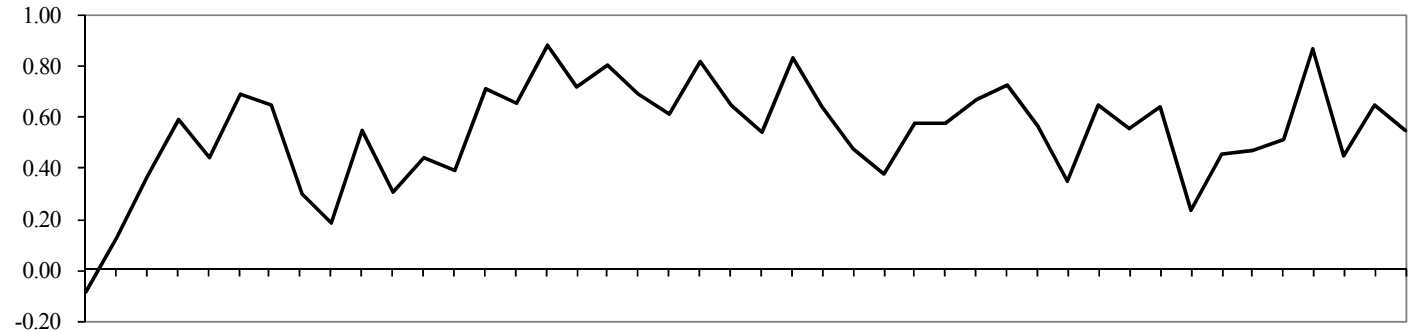

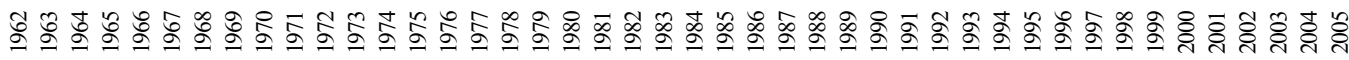


Figure 4. The small stock premium and IPO prices.

The average IPO first day closing price (solid), plotted against the low-priced-stock premium (short dash - right axis, inverted) and the small stock premium (long dash - right axis, inverted) in year $t-1$. The low-price-stock premium $P^{C M E}$ is the difference between the logs of the value-weighted market-to-book ratios for low and high priced firms. The small-stock premium $P^{S M B}$ is the difference between the log of the value-weighted market-to-book ratios for small and large firms. Data on IPO prices is from Jay Ritter.

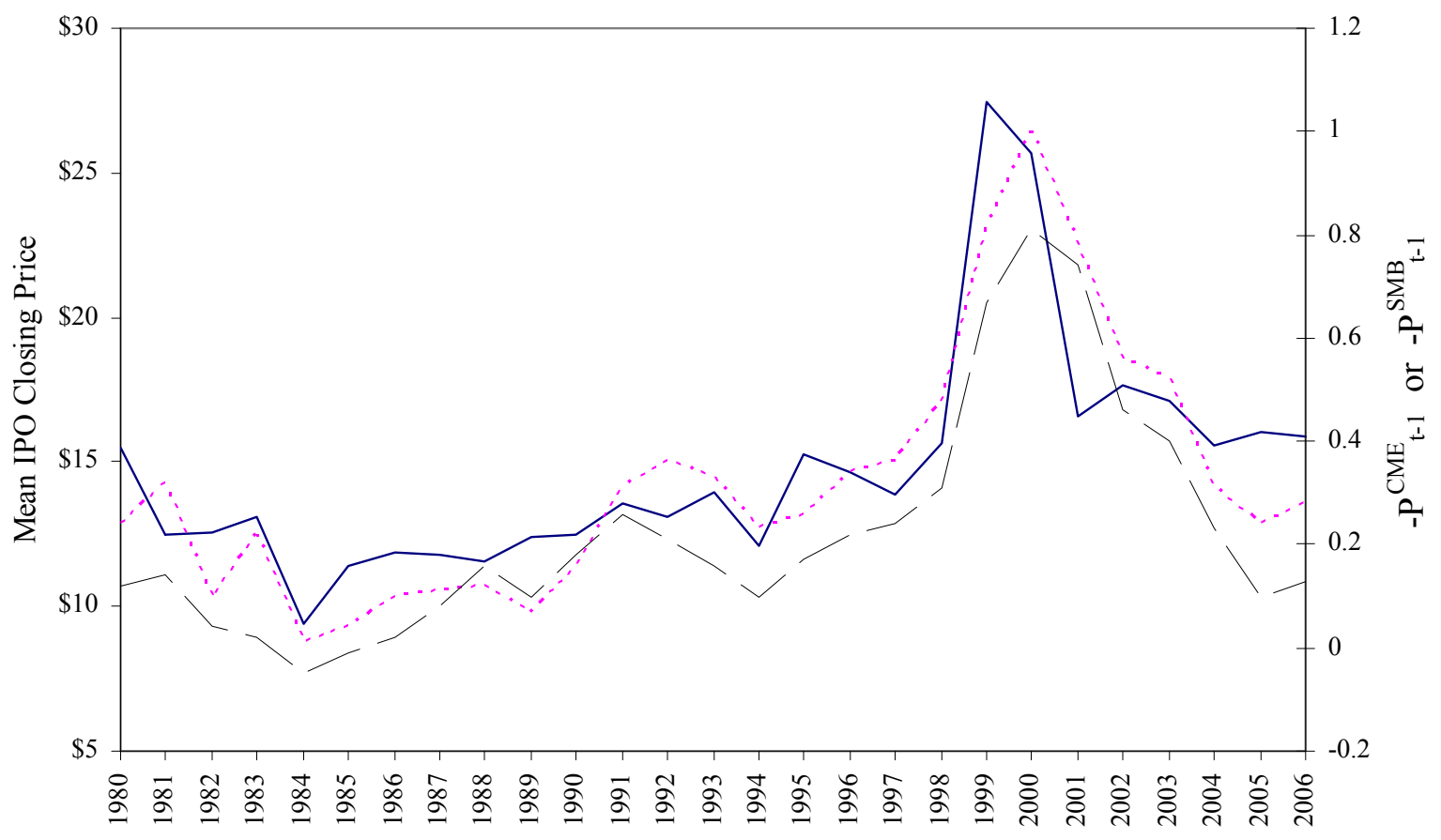


Figure 5. The low price premium and post split stock prices. The average post split price (solid - left axis) in year $t$ is plotted against the low price premium (dash - right axis, inverted) and small stock premium (long dash - right axis, inverted) in year $t$ - 1 . The average post split price is described in Table 1 and the low price premium and small stock premium are described in Table 2 .

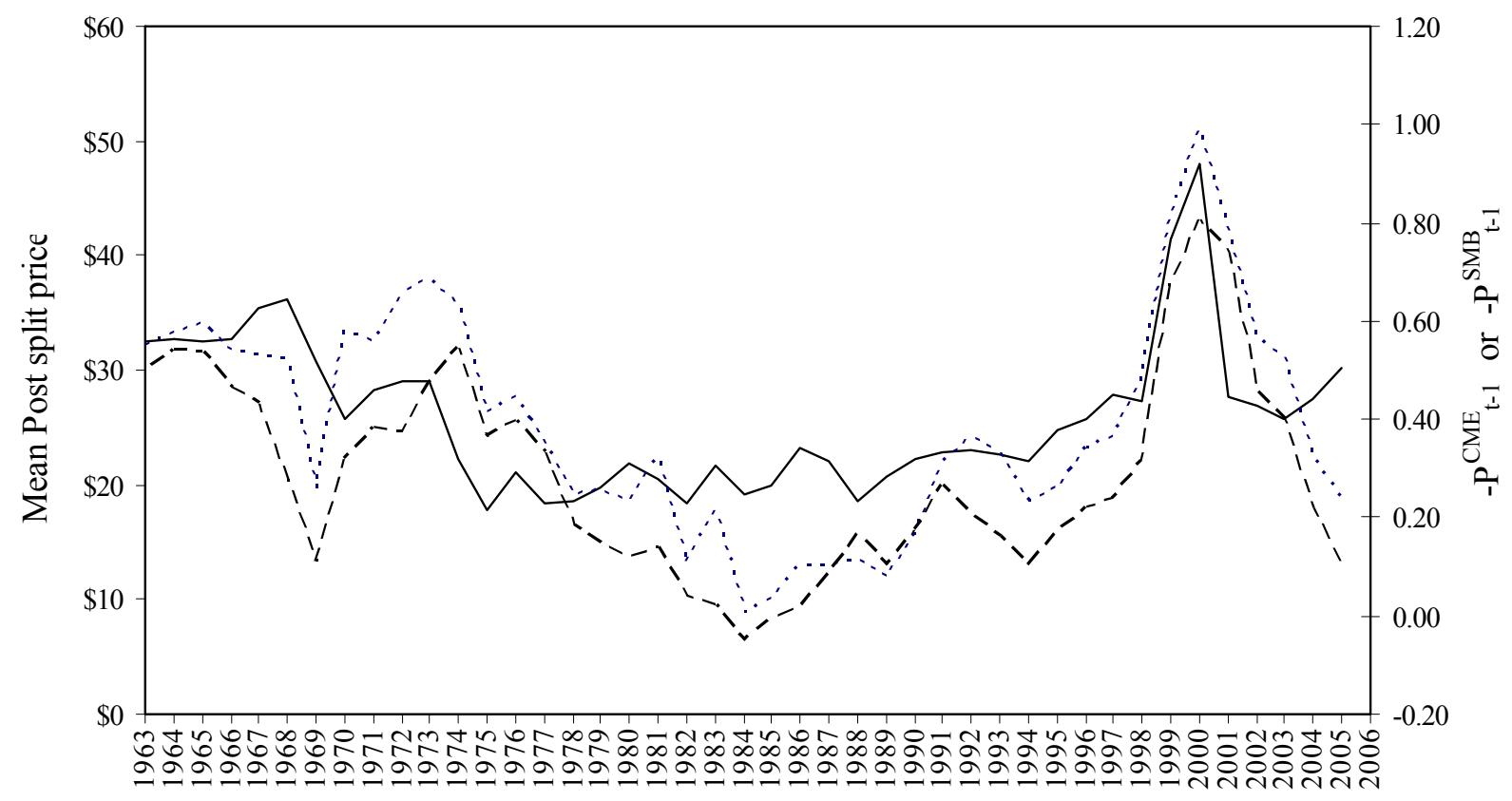


Table 1. Stock splits and post split prices. The number of splits, the average pre split price, the average post split price, and the average split ratio for splits, stock dividends, and reverse splits. Events with a CRSP distribution code of 5523 are divided into three categories: Splits have a split ratio greater than 1.25-for-1; stock dividends have a split ratio between 1.01-for-1 and 1.25for-1; and, reverse splits have a split ratio less than 1-for-1. The pre split price is the closing price on the day prior to the split. The post-split price is the pre split price times the reciprocal of the split ratio. The left most column lists the size of the full sample of CRSP firms. The right most two columns show a summary measure of splitting activity $m$ and the average offering price and first-day close for IPOs. $m$ is equal to the log of the ratio of the actual average stock price to the beginning of year stock price grown at the stock return excluding dividends, expressed in percentage terms. We report the equal-weighted average $m$ across all listed stocks.

\begin{tabular}{|c|c|c|c|c|c|c|c|c|c|c|c|c|c|}
\hline \multirow[b]{2}{*}{ Year } & \multirow[b]{2}{*}{ All } & \multicolumn{3}{|c|}{ Splits } & \multicolumn{3}{|c|}{ Stock Dividends } & \multicolumn{3}{|c|}{ Reverse Splits } & \multirow[b]{2}{*}{$m \%$} & \multicolumn{2}{|c|}{ IPO Prices } \\
\hline & & $\mathbf{N}$ & Pre & $\overline{\text { Post }}$ & $\mathbf{N}$ & Pre & $\overline{\text { Post }}$ & $\mathbf{N}$ & Pre & $\overline{\text { Post }}$ & & FirstDay & Offering \\
\hline 1963 & 2,074 & 57 & 63.96 & 32.49 & 2 & 34.50 & 27.60 & 5 & 2.59 & 10.94 & -4.00 & & \\
\hline 1964 & 2,138 & 99 & 70.12 & 32.78 & 13 & 82.85 & 66.28 & 10 & 3.10 & 9.07 & -3.62 & & \\
\hline 1965 & 2,135 & 132 & 72.39 & 32.46 & 13 & 28.74 & 22.99 & 5 & 2.21 & 10.74 & -4.56 & & \\
\hline 1966 & 2,177 & 163 & 64.61 & 32.68 & 8 & 32.75 & 26.20 & 4 & 2.47 & 10.72 & -4.77 & & \\
\hline 1967 & 2,180 & 108 & 70.21 & 35.50 & 10 & 38.36 & 30.88 & 1 & 17.00 & 34.00 & -3.48 & & \\
\hline 1968 & 2,179 & 218 & 70.91 & 36.21 & 15 & 32.73 & 26.19 & 3 & 6.17 & 18.21 & -4.99 & & \\
\hline 1969 & 2,264 & 210 & 59.83 & 30.74 & 1 & 16.63 & 13.30 & 3 & 4.35 & 19.77 & -4.60 & & \\
\hline 1970 & 2,336 & 46 & 50.06 & 25.65 & 1 & 18.63 & 14.90 & - & - & - & -0.99 & & \\
\hline 1971 & 2,431 & 94 & 51.46 & 28.28 & 9 & 30.18 & 24.30 & 5 & 7.10 & 16.85 & -2.77 & & \\
\hline 1972 & 5,300 & 148 & 56.69 & 29.08 & 9 & 27.94 & 22.54 & 5 & 4.28 & 14.45 & -1.81 & & \\
\hline 1973 & 4,993 & 178 & 56.33 & 29.00 & 23 & 37.32 & 30.26 & 11 & 2.99 & 9.36 & -3.21 & & \\
\hline 1974 & 4,699 & 78 & 43.48 & 22.29 & 20 & 13.99 & 11.34 & 5 & 7.81 & 16.74 & -2.09 & & \\
\hline 1975 & 4,737 & 101 & 33.50 & 17.86 & 19 & 16.09 & 13.01 & 7 & 1.96 & 9.35 & -2.95 & & \\
\hline 1976 & 4,802 & 203 & 38.48 & 21.01 & 53 & 15.06 & 12.16 & 11 & 1.93 & 7.02 & -4.67 & & \\
\hline 1977 & 4,730 & 236 & 33.23 & 18.47 & 58 & 17.35 & 14.01 & 6 & 1.63 & 9.08 & -4.48 & & \\
\hline 1978 & 4,659 & 340 & 33.27 & 18.55 & 66 & 19.81 & 15.91 & 9 & 1.13 & 4.17 & -5.30 & & \\
\hline 1979 & 4,612 & 272 & 37.44 & 19.77 & 83 & 19.19 & 15.76 & 5 & 1.35 & 19.15 & -5.45 & & \\
\hline 1980 & 4,780 & 456 & 40.94 & 21.94 & 78 & 20.79 & 16.76 & 5 & 3.24 & 9.56 & -7.43 & 15.47 & 12.96 \\
\hline 1981 & 5,130 & 505 & 38.98 & 20.53 & 67 & 21.42 & 17.26 & 14 & 4.66 & 11.83 & -8.69 & 12.48 & 11.74 \\
\hline 1982 & 5,100 & 226 & 31.69 & 18.44 & 67 & 18.69 & 15.12 & 24 & 0.83 & 5.70 & -5.88 & 12.53 & 11.11 \\
\hline 1983 & 5,720 & 780 & 40.56 & 21.60 & 73 & 20.98 & 16.86 & 29 & 2.81 & 7.03 & -8.54 & 13.08 & 11.88 \\
\hline 1984 & 5,837 & 349 & 34.86 & 19.15 & 49 & 15.85 & 12.78 & 28 & 0.55 & 4.00 & -5.80 & 9.37 & 9.16 \\
\hline 1985 & 5,800 & 480 & 36.10 & 19.98 & 78 & 18.09 & 14.65 & 40 & 3.34 & 9.44 & -6.03 & 11.42 & 10.80 \\
\hline 1986 & 6,061 & 738 & 44.39 & 23.17 & 75 & 20.51 & 16.49 & 25 & 1.99 & 8.09 & -7.88 & 11.87 & 11.15 \\
\hline 1987 & 6,360 & 554 & 41.75 & 22.15 & 81 & 21.31 & 17.27 & 62 & 1.09 & 8.85 & -3.85 & 11.76 & 11.11 \\
\hline 1988 & 6,099 & 205 & 33.08 & 18.53 & 54 & 19.72 & 16.02 & 52 & 0.92 & 6.05 & -2.43 & 11.55 & 10.94 \\
\hline 1989 & 5,902 & 292 & 37.76 & 20.76 & 64 & 21.34 & 17.27 & 60 & 1.41 & 6.86 & -1.71 & 12.38 & 11.51 \\
\hline 1990 & 5,737 & 197 & 43.50 & 22.26 & 38 & 20.77 & 16.73 & 93 & 0.75 & 3.82 & -0.51 & 12.48 & 11.23 \\
\hline 1991 & 5,792 & 248 & 41.39 & 22.79 & 41 & 15.89 & 12.87 & 84 & 1.45 & 6.85 & -1.50 & 13.53 & 12.08 \\
\hline 1992 & 5,930 & 416 & 44.60 & 23.10 & 45 & 19.73 & 15.94 & 140 & 1.02 & 5.87 & -0.43 & 13.08 & 11.76 \\
\hline 1993 & 6,451 & 477 & 40.55 & 22.62 & 61 & 22.73 & 18.26 & 104 & 2.15 & 9.88 & -1.96 & 13.95 & 12.26 \\
\hline 1994 & 6,780 & 345 & 42.75 & 22.05 & 52 & 23.98 & 19.35 & 84 & 2.60 & 7.82 & -1.07 & 12.10 & 11.01 \\
\hline 1995 & 7,021 & 447 & 45.83 & 24.77 & 47 & 20.10 & 16.20 & 87 & 1.32 & 6.78 & -2.01 & 15.28 & 12.49 \\
\hline 1996 & 7,489 & 562 & 47.73 & 25.69 & 51 & 24.47 & 19.65 & 87 & 1.86 & 6.59 & -2.39 & 14.68 & 12.39 \\
\hline 1997 & 7,483 & 630 & 51.36 & 27.87 & 59 & 26.60 & 21.43 & 88 & 2.81 & 7.96 & -2.81 & 13.88 & 12.05 \\
\hline 1998 & 7,020 & 630 & 52.28 & 27.23 & 60 & 25.60 & 20.79 & 157 & 1.04 & 4.61 & -2.43 & 15.63 & 12.61 \\
\hline 1999 & 6,665 & 405 & 81.53 & 41.44 & 40 & 24.51 & 20.49 & 103 & 0.98 & 4.39 & -1.97 & 27.43 & 14.80 \\
\hline 2000 & 6,357 & 442 & 97.23 & 48.07 & 12 & 23.55 & 19.47 & 52 & 3.43 & 10.23 & -1.35 & 25.68 & 14.82 \\
\hline 2001 & 5,653 & 180 & 49.08 & 27.74 & 27 & 23.21 & 19.55 & 101 & 0.69 & 3.95 & 0.32 & 16.56 & 14.46 \\
\hline 2002 & 5,232 & 186 & 48.24 & 26.96 & 23 & 21.69 & 17.65 & 94 & 1.04 & 7.41 & -0.01 & 17.62 & 15.95 \\
\hline 2003 & 4,917 & 193 & 45.40 & 25.69 & 32 & 26.25 & 21.73 & 68 & 1.02 & 5.16 & -1.28 & 17.13 & 15.21 \\
\hline 2004 & 4,856 & 262 & 52.20 & 27.57 & 27 & 26.20 & 21.48 & 42 & 2.88 & 12.00 & -1.82 & 15.54 & 13.61 \\
\hline 2005 & 4,775 & 260 & 56.03 & 30.22 & 33 & 24.49 & 20.00 & 50 & 1.85 & 7.82 & -0.88 & 16.04 & 14.32 \\
\hline 2006 & 4,714 & 206 & 57.22 & 29.82 & 32 & 23.48 & 19.98 & 57 & 2.51 & 9.22 & -1.01 & 15.89 & 13.65 \\
\hline
\end{tabular}


Table 2. The low price and small stock premia. The low price premium $P^{C M E}$ is the $\log$ difference in the average market-tobook ratios of low and high priced stocks. The small stock premium $P^{S M B}$ is the log difference in the average market-to-book ratios of small and large stocks. The market-to-book ratio is the ratio of the market value of the firm to its book value. Market value is equal to market equity at calendar year end (item 24 times item 25) plus book debt (item 6 minus book equity). Book equity is defined as stockholders' equity (generally item 216, with exceptions as noted in the text) minus preferred stock (item 10) plus deferred taxes and investment tax credits (item 35) and post retirement assets (item 330). All NYSE stocks with share codes of 10 or 11 are ranked each year by share price and market capitalization at the end of December. Low price i.e. cheap stocks (high price i.e. expensive) are stocks with share prices below the $30^{\text {th }}$ NYSE percentile (above the $70^{\text {th }}$ percentile) by share price. Small (large) stocks are stocks with market capitalizations below the $30^{\text {th }}$ NYSE percentile (above the $70^{\text {th }}$ percentile) by capitalization. Each premium is presented with both equal weighted (EW) and value weighted (VW) averages.

\begin{tabular}{|c|c|c|c|c|c|c|c|c|c|c|c|c|}
\hline \multirow[b]{3}{*}{ Year } & \multicolumn{6}{|c|}{ Low Price Premium } & \multicolumn{6}{|c|}{ Small Stock Premium } \\
\hline & \multicolumn{2}{|c|}{ Cheap MB } & \multicolumn{2}{|c|}{ Expensive MB } & \multicolumn{2}{|c|}{$P^{C M E}$} & \multicolumn{2}{|c|}{ Small Cap MB } & \multicolumn{2}{|c|}{ Large Cap MB } & \multicolumn{2}{|c|}{$P^{S M B}$} \\
\hline & VW & $\mathbf{E W}$ & VW & EW & VW & EW & VW & EW & VW & EW & VW & EW \\
\hline 1962 & 0.99 & 1.17 & 1.72 & 1.95 & -0.55 & -0.51 & 0.98 & 1.17 & 1.62 & 2.01 & -0.50 & -0.54 \\
\hline 1963 & 1.06 & 1.22 & 1.88 & 2.13 & -0.57 & -0.56 & 1.03 & 1.23 & 1.77 & 2.17 & -0.54 & -0.57 \\
\hline 1964 & 1.08 & 1.29 & 1.96 & 2.09 & -0.60 & -0.48 & 1.09 & 1.31 & 1.87 & 2.18 & -0.54 & -0.51 \\
\hline 1965 & 1.18 & 1.46 & 2.02 & 2.40 & -0.54 & -0.50 & 1.22 & 1.52 & 1.93 & 2.39 & -0.46 & -0.45 \\
\hline 1966 & 1.04 & 1.23 & 1.77 & 2.31 & -0.53 & -0.63 & 1.07 & 1.33 & 1.65 & 2.18 & -0.43 & -0.49 \\
\hline 1967 & 1.25 & 1.79 & 2.11 & 3.06 & -0.52 & -0.54 & 1.39 & 1.97 & 1.83 & 2.51 & -0.28 & -0.24 \\
\hline 1968 & 1.53 & 2.14 & 1.98 & 2.94 & -0.26 & -0.32 & 1.62 & 2.29 & 1.81 & 2.45 & -0.11 & -0.07 \\
\hline 1969 & 1.10 & 1.39 & 1.97 & 2.87 & -0.58 & -0.73 & 1.19 & 1.55 & 1.64 & 2.36 & -0.32 & -0.42 \\
\hline 1970 & 1.01 & 1.18 & 1.76 & 2.36 & -0.56 & -0.69 & 1.05 & 1.25 & 1.53 & 2.07 & -0.38 & -0.50 \\
\hline 1971 & 1.02 & 1.28 & 1.97 & 2.88 & -0.66 & -0.81 & 1.13 & 1.42 & 1.64 & 2.49 & -0.37 & -0.56 \\
\hline 1972 & 1.04 & 1.26 & 2.07 & 3.05 & -0.69 & -0.88 & 1.12 & 1.42 & 1.79 & 2.73 & -0.47 & -0.65 \\
\hline 1973 & 0.84 & 0.91 & 1.58 & 2.17 & -0.63 & -0.87 & 0.86 & 0.96 & 1.48 & 2.15 & -0.54 & -0.81 \\
\hline 1974 & 0.75 & 0.75 & 1.14 & 1.32 & -0.42 & -0.57 & 0.75 & 0.78 & 1.08 & 1.38 & -0.36 & -0.57 \\
\hline 1975 & 0.82 & 0.86 & 1.28 & 1.49 & -0.45 & -0.55 & 0.82 & 0.88 & 1.22 & 1.52 & -0.40 & -0.55 \\
\hline 1976 & 0.92 & 0.98 & 1.31 & 1.48 & -0.35 & -0.41 & 0.90 & 1.01 & 1.26 & 1.47 & -0.34 & -0.38 \\
\hline 1977 & 0.90 & 1.01 & 1.15 & 1.36 & -0.25 & -0.30 & 0.92 & 1.04 & 1.11 & 1.26 & -0.19 & -0.19 \\
\hline 1978 & 0.89 & 1.02 & 1.15 & 1.37 & -0.26 & -0.30 & 0.93 & 1.06 & 1.08 & 1.21 & -0.15 & -0.13 \\
\hline 1979 & 0.93 & 1.31 & 1.18 & 1.59 & -0.24 & -0.19 & 0.98 & 1.33 & 1.11 & 1.31 & -0.12 & 0.02 \\
\hline 1980 & 0.95 & 1.73 & 1.31 & 2.04 & -0.32 & -0.16 & 1.06 & 1.78 & 1.22 & 1.64 & -0.14 & 0.08 \\
\hline 1981 & 1.00 & 1.45 & 1.11 & 1.55 & -0.10 & -0.07 & 1.01 & 1.46 & 1.05 & 1.33 & -0.04 & 0.09 \\
\hline 1982 & 1.00 & 1.54 & 1.24 & 1.83 & -0.22 & -0.17 & 1.09 & 1.57 & 1.11 & 1.54 & -0.02 & 0.02 \\
\hline 1983 & 1.21 & 1.82 & 1.22 & 1.63 & -0.01 & 0.11 & 1.24 & 1.79 & 1.18 & 1.54 & 0.05 & 0.15 \\
\hline 1984 & 1.10 & 1.53 & 1.14 & 1.43 & -0.04 & 0.07 & 1.12 & 1.51 & 1.11 & 1.42 & 0.01 & 0.06 \\
\hline 1985 & 1.14 & 1.73 & 1.26 & 1.68 & -0.10 & 0.03 & 1.20 & 1.73 & 1.22 & 1.60 & -0.02 & 0.08 \\
\hline 1986 & 1.17 & 1.70 & 1.30 & 1.82 & -0.11 & -0.07 & 1.18 & 1.69 & 1.28 & 1.75 & -0.08 & -0.03 \\
\hline 1987 & 1.13 & 1.47 & 1.27 & 1.68 & -0.12 & -0.13 & 1.07 & 1.46 & 1.26 & 1.74 & -0.16 & -0.18 \\
\hline 1988 & 1.16 & 1.58 & 1.25 & 1.66 & -0.07 & -0.05 & 1.13 & 1.59 & 1.25 & 1.66 & -0.10 & -0.04 \\
\hline 1989 & 1.20 & 1.65 & 1.41 & 1.92 & -0.16 & -0.15 & 1.16 & 1.67 & 1.39 & 1.90 & -0.18 & -0.13 \\
\hline 1990 & 1.00 & 1.31 & 1.36 & 1.94 & -0.31 & -0.39 & 1.01 & 1.38 & 1.31 & 1.78 & -0.26 & -0.25 \\
\hline 1991 & 1.11 & 1.63 & 1.59 & 2.64 & -0.36 & -0.48 & 1.19 & 1.79 & 1.47 & 2.33 & -0.21 & -0.26 \\
\hline 1992 & 1.17 & 1.83 & 1.63 & 2.44 & -0.33 & -0.29 & 1.31 & 1.93 & 1.54 & 2.23 & -0.16 & -0.14 \\
\hline 1993 & 1.29 & 2.04 & 1.63 & 2.55 & -0.23 & -0.22 & 1.45 & 2.11 & 1.60 & 2.26 & -0.10 & -0.07 \\
\hline 1994 & 1.24 & 1.77 & 1.61 & 2.41 & -0.26 & -0.31 & 1.32 & 1.84 & 1.56 & 2.02 & -0.17 & -0.09 \\
\hline 1995 & 1.32 & 1.98 & 1.86 & 3.08 & -0.34 & -0.44 & 1.41 & 2.08 & 1.75 & 2.52 & -0.22 & -0.19 \\
\hline 1996 & 1.37 & 2.01 & 1.97 & 2.94 & -0.36 & -0.38 & 1.46 & 2.09 & 1.85 & 2.52 & -0.24 & -0.19 \\
\hline 1997 & 1.40 & 2.01 & 2.26 & 3.03 & -0.48 & -0.41 & 1.53 & 2.09 & 2.09 & 2.73 & -0.31 & -0.27 \\
\hline 1998 & 1.16 & 1.69 & 2.62 & 3.66 & -0.81 & -0.77 & 1.23 & 1.79 & 2.41 & 3.17 & -0.67 & -0.57 \\
\hline 1999 & 1.12 & 2.06 & 3.03 & 5.08 & -1.00 & -0.90 & 1.23 & 2.23 & 2.77 & 4.22 & -0.81 & -0.64 \\
\hline 2000 & 1.08 & 1.57 & 2.35 & 3.87 & -0.78 & -0.90 & 1.03 & 1.62 & 2.16 & 3.31 & -0.74 & -0.71 \\
\hline 2001 & 1.24 & 1.77 & 2.18 & 2.85 & -0.56 & -0.48 & 1.19 & 1.82 & 1.88 & 2.59 & -0.46 & -0.35 \\
\hline 2002 & 1.15 & 1.52 & 1.94 & 2.28 & -0.52 & -0.41 & 1.09 & 1.55 & 1.63 & 2.08 & -0.40 & -0.29 \\
\hline 2003 & 1.44 & 2.37 & 1.97 & 2.54 & -0.31 & -0.07 & 1.42 & 2.39 & 1.78 & 2.36 & -0.23 & 0.01 \\
\hline 2004 & 1.56 & 2.45 & 1.98 & 2.57 & -0.24 & -0.05 & 1.57 & 2.50 & 1.74 & 2.40 & -0.10 & 0.04 \\
\hline 2005 & 1.48 & 2.30 & 1.95 & 2.50 & -0.28 & -0.08 & 1.55 & 2.35 & 1.77 & 2.47 & -0.13 & -0.05 \\
\hline
\end{tabular}


Table 3. The split announcement premium. The split announcement premium $A$ is the scaled abnormal return from the day before split announcement through ten days after the effective date. The cumulative abnormal return CAR is equal to difference between the stock return and the value weighted market return over this interval. The split announcement premium is equal to the CAR scaled by the square root of the number of days in the window times the standard deviation of daily returns in the 100 trading days ending five days prior to the split announcement date. The t-statistic is from Campbell et al. (2001) and tests the hypothesis that the average split announcement return is equal to zero.

\begin{tabular}{|c|c|c|c|}
\hline \multirow[b]{2}{*}{ Year } & \multicolumn{3}{|c|}{ Split Announcement Premium } \\
\hline & CAR & $A$ & [t-stat] \\
\hline 1962 & 0.24 & -0.09 & {$[-0.66]$} \\
\hline 1963 & 1.92 & 0.13 & {$[0.99]$} \\
\hline 1964 & 3.45 & 0.37 & [4.01] \\
\hline 1965 & 9.10 & 0.59 & [6.99] \\
\hline 1966 & 6.70 & 0.44 & [4.98] \\
\hline 1967 & 9.84 & 0.69 & {$[8.28]$} \\
\hline 1968 & 9.67 & 0.65 & {$[9.22]$} \\
\hline 1969 & 4.43 & 0.29 & [3.68] \\
\hline 1970 & 2.47 & 0.18 & [1.23] \\
\hline 1971 & 8.38 & 0.55 & {$[5.77]$} \\
\hline 1972 & 4.29 & 0.30 & [3.39] \\
\hline 1973 & 6.75 & 0.44 & {$[5.46]$} \\
\hline 1974 & 7.80 & 0.39 & [3.27] \\
\hline 1975 & 11.50 & 0.71 & {$[7.50]$} \\
\hline 1976 & 8.07 & 0.65 & {$[10.14]$} \\
\hline 1977 & 9.93 & 0.88 & [14.48] \\
\hline 1978 & 9.83 & 0.72 & [14.11] \\
\hline 1979 & 10.79 & 0.80 & [13.90] \\
\hline 1980 & 11.30 & 0.69 & [16.05] \\
\hline 1981 & 7.87 & 0.61 & [13.60] \\
\hline 1982 & 11.94 & 0.82 & [14.76] \\
\hline 1983 & 9.47 & 0.64 & [17.90] \\
\hline 1984 & 5.43 & 0.54 & [10.06] \\
\hline 1985 & 9.90 & 0.83 & [19.03] \\
\hline 1986 & 8.91 & 0.64 & [17.52] \\
\hline 1987 & 6.48 & 0.47 & [11.20] \\
\hline 1988 & 8.84 & 0.37 & [5.87] \\
\hline 1989 & 7.42 & 0.57 & [10.75] \\
\hline 1990 & 7.23 & 0.57 & [8.11] \\
\hline 1991 & 11.23 & 0.67 & [11.38] \\
\hline 1992 & 11.80 & 0.72 & [15.25] \\
\hline 1993 & 9.50 & 0.56 & [12.74] \\
\hline 1994 & 7.31 & 0.35 & [6.51] \\
\hline 1995 & 10.78 & 0.65 & [13.99] \\
\hline 1996 & 10.71 & 0.55 & [12.66] \\
\hline 1997 & 9.03 & 0.64 & [14.28] \\
\hline 1998 & 5.06 & 0.23 & [4.86] \\
\hline 1999 & 17.70 & 0.45 & [9.20] \\
\hline 2000 & 12.08 & 0.46 & [8.73] \\
\hline 2001 & 8.54 & 0.51 & [6.85] \\
\hline 2002 & 9.59 & 0.86 & [12.16] \\
\hline 2003 & 7.26 & 0.45 & [6.89] \\
\hline 2004 & 8.31 & 0.65 & [10.67] \\
\hline 2005 & 6.06 & 0.54 & [9.06] \\
\hline
\end{tabular}


Table 4. The low price and small stock premia and splitting activity. Regressions of measures of splitting activity on the low price and small stock premia.

$$
s_{t}=a+b P_{t-1}^{C M E}+c P_{t-1}^{S M B}+d A_{t-1}+e p_{t-1}^{E W}+f r_{t}^{E W}+u_{t} \text { and } m_{t}=a+b P_{t-1}^{C M E}+c P_{t-1}^{S M B}+d A_{t-1}+e p_{t-1}^{E W}+f r_{t}^{E W}+u_{t}
$$

where $s$ is the number of splits in year $t$, expressed as a percentage of the number of firms, shown in Table $1, m$ is a summary measure of splitting activity in year $t$ equal to the log of the ratio of the actual average stock price to the $t-1$ stock price grown at the stock return excluding dividends, $P^{C M E}$ and $P^{S M B}$ are the low price and small stock premia shown in Table 2, A is the split announcement premium shown in Table 3. Panel A shows univariate regressions for each of the three premia. Panel B controls for the log equal weighted average stock price $p^{E W}$ in year $t-1$ and the equal weighted return $r$ excluding distributions at time $t$. We perform separate univariate regressions in Panel A for value and equal weighted versions of the high price and large stock premia. Each regression has 44 observations. All right-hand-side variables have been standardized to unit variance. T-statistics use standard errors that are robust to heteroskedasticity and autocorrelation of up to three lags.

\begin{tabular}{|c|c|c|c|c|c|c|c|c|c|c|c|c|c|c|c|c|c|c|}
\hline \multirow[b]{3}{*}{ Weighting } & \multicolumn{6}{|c|}{ Low Price Premium $P^{C M E}$} & \multicolumn{6}{|c|}{ Small Stock Premium $P^{S M B}$} & \multicolumn{6}{|c|}{ Split Announcement Premium A } \\
\hline & \multicolumn{3}{|c|}{ Split \% s } & \multicolumn{3}{|c|}{ Splitting Activity $m$} & \multicolumn{3}{|c|}{ Split \% s } & \multicolumn{3}{|c|}{ Splitting Activity $m$} & \multicolumn{3}{|c|}{ Split \% s } & \multicolumn{3}{|c|}{ Splitting Activity $m$} \\
\hline & $\mathbf{b}$ & [t] & $\mathbf{R}^{2}$ & $\mathbf{b}$ & [t] & $\mathbf{R}^{2}$ & c & [t] & $\mathbf{R}^{2}$ & c & [t] & $\mathbf{R}^{2}$ & d & [t] & $\mathbf{R}^{2}$ & d & [t] & $\mathbf{R}^{2}$ \\
\hline \multicolumn{19}{|c|}{ Panel A. Univariate Regressions } \\
\hline Value Weighted & 0.94 & {$[2.3]$} & 0.11 & -0.85 & {$[-2.1]$} & 0.14 & 1.33 & {$[3.0]$} & 0.21 & -0.93 & {$[-2.1]$} & 0.16 & & & & & & \\
\hline Equal Weighted & 1.15 & {$[3.1]$} & 0.16 & -0.86 & {$[-2.0]$} & 0.14 & 1.56 & [4.7] & 0.29 & -0.88 & {$[-1.8]$} & 0.15 & 1.62 & {$[3.4]$} & 0.31 & -0.79 & {$[-1.6]$} & 0.12 \\
\hline \multicolumn{19}{|c|}{ Panel B. Multivariate Regressions } \\
\hline Value Weighted & 1.33 & {$[2.8]$} & 0.24 & -1.00 & {$[-2.4]$} & 0.19 & 1.53 & {$[3.0]$} & 0.32 & -0.99 & {$[-2.2]$} & 0.20 & & & & & & \\
\hline Equal Weighted & 1.32 & {$[3.0]$} & 0.25 & -0.90 & {$[-1.8]$} & 0.17 & 1.63 & {$[4.3]$} & 0.37 & -0.89 & {$[-1.7]$} & 0.17 & 1.82 & {$[4.2]$} & 0.43 & -0.82 & {$[-1.7]$} & 0.14 \\
\hline
\end{tabular}


Table 5. The low price and small stock premia and IPO and post-split stock prices. Regressions of price levels on the low price and small stock premia.

$$
p_{t}^{I P O}=a+b P_{t-1}^{C M E}+c P_{t-1}^{S M B}+d A_{t-1}+e p_{t-1}^{E W}+f r_{t}^{E W}+u_{t} \text { and } p_{t}=a+b P_{t-1}^{C M E}+c P_{t-1}^{S M B}+d A_{t-1}+e p_{t-1}^{E W}+f r_{t}^{E W}+u_{t}
$$

where $p^{I P O}$ is the $\log$ of the average IPO price in year $t, p$ is the $\log$ of the average post-split stock price in year $t, P^{C M E}$ and $P^{S M B}$ are the low price and small stock premia shown in Table 2, $A$ is the split announcement premium shown in Table 3. Panel A shows univariate regressions for each of the three premia. Panel B controls for the log equal weighted average stock price $p^{E W}$ in year $t-1$ and the equal weighted return $r$ excluding distributions at time $t$. We perform separate univariate regressions in Panel A for value and equal weighted versions of the high price and large stock premia. Each $p^{I P O}$ regression has 27 observations, and each $p$ regression has 44 observations. All right-hand-side variables have been standardized to unit variance. T-statistics use standard errors that are robust to heteroskedasticity and autocorrelation of up to three lags.

\begin{tabular}{|c|c|c|c|c|c|c|c|c|c|c|c|c|c|c|c|c|c|c|}
\hline \multirow[b]{3}{*}{ Weighting } & \multicolumn{6}{|c|}{ Low Price Premium $P^{C M E}$} & \multicolumn{6}{|c|}{ Small Stock Premium $P^{S M B}$} & \multicolumn{6}{|c|}{ Split Announcement Premium A } \\
\hline & \multicolumn{3}{|c|}{ IPO Price $p_{I P O}$} & \multicolumn{3}{|c|}{ Post Split Price p } & \multicolumn{3}{|c|}{ IPO Price $p_{I P O}$} & \multicolumn{3}{|c|}{ Post Split Price $p$} & \multicolumn{3}{|c|}{ IPO Price $p_{I P O}$} & \multicolumn{3}{|c|}{ Post Split Price p } \\
\hline & b & [t] & $\mathbf{R}^{2}$ & $\mathbf{b}$ & [t] & $\mathbf{R}^{2}$ & c & [t] & $\mathbf{R}^{2}$ & c & [t] & $\mathbf{R}^{2}$ & d & [t] & $\mathbf{R}^{2}$ & d & [t] & $\mathbf{R}^{2}$ \\
\hline \multicolumn{19}{|c|}{ Panel A. Univariate Regressions } \\
\hline Value Weighted & -0.19 & {$[-10.2]$} & 0.78 & -0.17 & {$[-6.5]$} & 0.52 & -0.18 & {$[-7.0]$} & 0.71 & -0.15 & {$[-5.0]$} & 0.41 & & & & & & \\
\hline Equal Weighted & -0.18 & {$[-4.9]$} & 0.59 & -0.12 & {$[-2.8]$} & 0.28 & -0.20 & {$[-4.6]$} & 0.54 & -0.11 & {$[-2.1]$} & 0.21 & -0.12 & {$[-1.4]$} & 0.15 & -0.10 & {$[-3.5]$} & 0.18 \\
\hline \multicolumn{19}{|c|}{ Panel B. Multivariate Regressions } \\
\hline Value Weighted & -0.17 & {$[-8.6]$} & 0.83 & -0.12 & {$[-4.0]$} & 0.80 & -0.16 & {$[-8.0]$} & 0.84 & -0.12 & {$[-4.5]$} & 0.81 & & & & & & \\
\hline Equal Weighted & -0.16 & {$[-6.8]$} & 0.76 & -0.09 & {$[-2.8]$} & 0.72 & -0.18 & {$[-6.6]$} & 0.78 & -0.09 & {$[-3.1]$} & 0.72 & -0.14 & {$[-2.2]$} & 0.51 & -0.07 & {$[-2.6]$} & 0.64 \\
\hline
\end{tabular}


Table 6. The low price and small stock premia and post-split stock prices: Robustness checks. Regressions of price levels on the low price and small stock premia.

$$
p_{t}=a+b P_{t-1}^{C M E}+c P_{t-1}^{S M B}+e p_{t-1}^{E W}+f r_{t}^{E W}+u_{t}
$$

where $p$ is the log of the average post-split stock price in year $t, P^{C M E}$ and $P^{S M B}$ are the low price and small stock premia shown in Table 2. All regressions control for the log equal weighted average stock price $p^{E W}$ in year $t-1$ and the equal weighted return $r$ excluding distributions at time $t$. All right-hand-side variables are standardized to have unit variance. T-statistics use standard errors that are robust to heteroskedasticity and autocorrelation of up to three lags.

\begin{tabular}{|c|c|c|c|c|c|c|c|}
\hline \multirow[b]{2}{*}{ Specification } & \multirow[b]{2}{*}{$\mathbf{N}$} & \multicolumn{3}{|c|}{ Low Price Premium $P^{C M E}$} & \multicolumn{3}{|c|}{ Small Stock Premium $P^{S M B}$} \\
\hline & & $\mathbf{b}$ & [t] & $\mathbf{R}^{2}$ & c & {$[t]$} & $\mathbf{R}^{2}$ \\
\hline Base Case & 44 & -0.12 & {$[-4.00]$} & 0.80 & -0.12 & {$[-4.52]$} & 0.81 \\
\hline First Half & 22 & -0.13 & {$[-6.26]$} & 0.87 & -0.13 & {$[-5.95]$} & 0.87 \\
\hline Second Half & 22 & -0.12 & {$[-6.46]$} & 0.92 & -0.11 & {$[-7.45]$} & 0.93 \\
\hline Time Trend Control & 44 & -0.12 & {$[-6.36]$} & 0.86 & -0.12 & {$[-7.55]$} & 0.88 \\
\hline Differences & 43 & -0.12 & {$[-2.08]$} & 0.30 & -0.10 & {$[-1.96]$} & 0.20 \\
\hline Return-Based CME or SMB & 44 & -0.10 & {$[-3.82]$} & 0.69 & -0.12 & {$[-3.90]$} & 0.74 \\
\hline IPO Offer Price & 27 & -0.08 & {$[-5.01]$} & 0.72 & -0.08 & {$[-5.55]$} & 0.75 \\
\hline Large Firms & 44 & -0.10 & {$[-4.11]$} & 0.59 & -0.09 & {$[-4.25]$} & 0.58 \\
\hline Small Firms & 44 & 0.01 & {$[0.34]$} & 0.70 & 0.01 & {$[0.23]$} & 0.70 \\
\hline $\mathrm{M} / \mathrm{B}_{\mathrm{High}}$ & 44 & 0.15 & {$[6.81]$} & 0.88 & 0.21 & {$[8.44]$} & 0.90 \\
\hline $\mathrm{M} / \mathrm{B}_{\text {Low }}$ & & -0.04 & {$[-1.92]$} & & -0.06 & {$[-2.96]$} & \\
\hline
\end{tabular}


Table 7. The low price and small stock premia and splitting activity: Firm level panel regressions. Regressions of measures of splitting activity on the high price and large stock premia.

$$
\begin{gathered}
\operatorname{Pr}\left(s_{i, t}=1\right)=a+b P_{t-1}^{C M E}+e p_{i, t-1}+f r_{i, t}+g N Y S E D_{i, t}+h p_{i, t-1}^{\text {Industry }}+j p_{i, t-1}^{\text {LastSplit }}+u_{i, t} \text { and } \\
m_{i, t}=p_{i, t}-p_{i, t-1}-r_{i, t}=a+b P_{t-1}^{C M E}+e p_{i, t-1}+f r_{i, t}+g N Y S E D_{i, t}+j p_{i, t-1}^{\text {Industry }}+h p_{i, t-1}^{\text {LastSplit }}+u_{i, t}
\end{gathered}
$$

where $s$ is an indicator variable equal to one if firm $i$ splits in year $t, m$ is a summary measure of splitting activity in year $t$ equal to the log of the ratio of the stock price $p$ for firm $i$ at year end $t$ to the stock price $p$ for firm $i$ at year end $t-1$ grown at the stock return $r$ for firm $i$ in year $t$ excluding dividends, and $P^{C M E}$ is the low price premium shown in Table 2 . Panel A shows results for $s$, and Panel B shows results for $m$. Additional control variables include the NYSE market capitalization decile NYSED for firm $i$, the log average price $p^{\text {Industry }}$ in the matched Fama and French (1997) industry, and the log of the post split price $p^{\text {LastSplit }}$ from the most recent split for firm $i$. T- and z-statistics use standard errors that

\begin{tabular}{|c|c|c|c|c|c|c|c|c|c|c|c|c|c|c|}
\hline \multirow[b]{2}{*}{ Specification } & \multicolumn{2}{|c|}{$P^{C M E}$} & \multicolumn{2}{|c|}{$p$} & \multicolumn{2}{|c|}{$r$} & \multicolumn{2}{|c|}{ NYSED } & \multicolumn{2}{|c|}{$p^{\text {Industry }}$} & \multicolumn{2}{|c|}{$p^{\text {LastSplit }}$} & \multirow[b]{2}{*}{$\mathbf{R}^{2}$} & \multirow[b]{2}{*}{$\mathbf{N}$} \\
\hline & $\mathbf{b}$ & [t] & e & [t] & $\mathbf{f}$ & [t] & g & [t] & $\mathbf{h}$ & [t] & $\mathbf{j}$ & [t] & & \\
\hline \multicolumn{15}{|c|}{ Panel A. $($ Split $=1)=s$} \\
\hline Base Case & 0.50 & {$[3.03]$} & 3.62 & {$[9.57]$} & 3.99 & {$[13.63]$} & -0.38 & {$[-8.72]$} & & & & & 0.24 & 211,977 \\
\hline Industry Control & 0.45 & [2.99] & 3.59 & {$[10.08]$} & 3.81 & {$[13.43]$} & -0.34 & {$[-9.39]$} & -0.93 & {$[-6.08]$} & & & 0.24 & 211,977 \\
\hline Last Split Control & 0.77 & [3.12] & 0.76 & {$[10.75]$} & 7.48 & {$[16.25]$} & -0.59 & {$[-9.24]$} & & & -2.92 & {$[-8.44]$} & 0.24 & 89,989 \\
\hline \multicolumn{15}{|c|}{ Panel B. Splitting Activity $m$} \\
\hline Base Case & -0.79 & {$[-1.89]$} & -6.92 & {$[-17.75]$} & -7.34 & {$[-11.25]$} & 0.95 & {$[13.80]$} & & & & & 0.12 & 211,977 \\
\hline Industry Control & -0.73 & {$[-1.81]$} & -6.99 & {$[-17.77]$} & -7.35 & {$[-11.29]$} & 0.89 & {$[12.16]$} & 1.27 & {$[4.80]$} & & & 0.12 & 211,977 \\
\hline Last Split Control & -0.48 & {$[-1.06]$} & -8.80 & {$[-19.10]$} & -9.36 & {$[-11.16]$} & 0.89 & [11.08] & & & 2.89 & {$[9.37]$} & 0.13 & 89,989 \\
\hline
\end{tabular}
are clustered by year. The coefficients and associated z-statistics shown for the probit regressions denote the marginal effects. 
Table 8. The low price and small stock premia and IPO and post-split prices: Firm level event regressions. Regressions of the IPO and post-split prices on firm-level determinants and the low price and small stock premia.

$$
\begin{gathered}
p_{i, t}^{I P O}=a+b P_{t-1}^{C M E}+e N Y S E D_{i, t}+f p_{i, t-1}^{\text {Industry }}+u_{i, t} \text { and } \\
p_{i, t}=a+b P_{t-1}^{C M E}+c p_{i, t-1}^{\text {LastSplit }}+d r_{i, t}^{\text {LastSplit }}+e N Y S E D_{i, t}+f p_{i, t-1}^{\text {Industry }}+u_{i, t}
\end{gathered}
$$

where $p^{I P O}$ is the log first day closing price for newly listed firms, $p$ is the log month-end price for stocks that split in month $t$, and $P^{C M E}$ is the low price premium shown in Table 2 . Panel A shows results for $p^{I P O}$ and Panel B shows results for $p$. Additional control variables include the NYSE market capitalization decile NYSED for firm $i$, the average price $p^{\text {Industry }}$ in the matched Fama and French (1997) industry, the log of the split price $p^{\text {LastSplit }}$ from the most recent split for firm $i$, and the log of the ex-dividend return $r^{\text {LastSplit }}$ since the last split. For firms that have not split before, $p^{\text {Lastsplit }}$ is the log month-end price following the IPO, and $r^{\text {LastSplit }}$ is the log return since the IPO. T-statistics use standard errors

\begin{tabular}{|c|c|c|c|c|c|c|c|c|c|c|c|c|}
\hline \multirow[b]{2}{*}{ Specification } & \multicolumn{2}{|c|}{$P^{C M E}$} & \multicolumn{2}{|c|}{$p^{\text {LastSplit }}$} & \multicolumn{2}{|c|}{$r^{\text {LastSplit }}$} & \multicolumn{2}{|c|}{ NYSED } & \multicolumn{2}{|c|}{$p^{\text {Industry }}$} & \multirow[b]{2}{*}{$\mathbf{R}^{2}$} & \multirow[b]{2}{*}{$\mathbf{N}$} \\
\hline & b & [t] & c & [t] & d & [t] & e & [t] & $\mathbf{f}$ & [t] & & \\
\hline \multicolumn{13}{|c|}{ Panel A. IPO Price $p^{I P O}$} \\
\hline Base Case & -0.04 & {$[-1.92]$} & & & & & 0.19 & {$[27.71]$} & & & 0.50 & 6,719 \\
\hline Industry Control & -0.03 & {$[-1.46]$} & & & & & 0.19 & {$[26.62]$} & 0.11 & {$[5.93]$} & 0.51 & 6,719 \\
\hline \multicolumn{13}{|c|}{ Panel B. Post Split Price $p$} \\
\hline Base Case & -0.05 & {$[-7.61]$} & 0.54 & {$[17.56]$} & 0.51 & {$[21.56]$} & 0.05 & {$[13.88]$} & & & 0.75 & 13,308 \\
\hline Industry Control & -0.04 & {$[-8.33]$} & 0.52 & [17.18] & 0.49 & [21.36] & 0.05 & {$[14.32]$} & 0.09 & {$[5.73]$} & 0.75 & 13,308 \\
\hline
\end{tabular}
that are clustered by year. 
Table 9. Splitting activity, post-split prices and the future returns on high price and large stocks. Regressions of future excess returns of low price stocks over high price stocks, or of small stocks over large stocks, on splitting activity and post-split price levels, controlling for overall price levels.

$$
R_{t+1}=a+b s_{t}+c p_{t-1}^{E W}+u_{t} \text { and } R_{t+1}=a+b p_{t}+c p_{t-1}^{E W}+u_{t}
$$

where $s$ is the number of splits in year $t$, expressed as a percentage of the number of firms, shown in Table $1,, p$ is the log of the average post-split stock price in year $t$, and $p^{E W}$ is the log equal weighted average stock price in year $t$ - 1 . T-statistics in the second stage regression use standard errors that are robust to heteroskedasticity and autocorrelation up to three years of lags.

\begin{tabular}{|c|c|c|c|c|c|c|c|c|c|c|c|c|c|}
\hline & \multirow[b]{3}{*}{$\mathbf{N}$} & \multicolumn{6}{|c|}{ Split \% s } & \multicolumn{6}{|c|}{ Post Split Price $p$} \\
\hline & & \multicolumn{3}{|c|}{$R_{t+1} \mathrm{EW}$} & \multicolumn{3}{|c|}{$R_{t+1} \mathrm{VW}$} & \multicolumn{3}{|c|}{$R_{t+1} \mathrm{EW}$} & \multicolumn{3}{|c|}{$R_{t+1} \mathrm{VW}$} \\
\hline & & b & [t] & $\mathbf{R}^{2}$ & $\mathbf{b}$ & [t] & $\mathbf{R}^{2}$ & $\mathbf{b}$ & [t] & $\mathbf{R}^{2}$ & b & [t] & $\mathbf{R}^{2}$ \\
\hline \multicolumn{14}{|c|}{ Panel A: Relative returns of low-price stocks over high-price stocks } \\
\hline$R_{\text {Cheapt }+1}-R_{\text {Expt }+1}$ & 43 & -2.62 & {$[-3.53]$} & 0.11 & -1.96 & {$[-2.43]$} & 0.09 & 0.40 & [2.62] & 0.08 & 0.28 & [2.84] & 0.06 \\
\hline$R_{\text {Cheapt }+2}-R_{\text {Expt+2 }}$ & 42 & -4.70 & {$[-2.92]$} & 0.11 & -3.52 & {$[-1.98]$} & 0.10 & 0.60 & {$[2.27]$} & 0.06 & 0.43 & {$[2.22]$} & 0.05 \\
\hline$R_{\text {Cheapt }+3}-R_{\text {Expt }+3}$ & 41 & -8.27 & {$[-3.24]$} & 0.20 & -6.49 & {$[-2.35]$} & 0.17 & 1.02 & {$[2.58]$} & 0.10 & 0.80 & {$[2.70]$} & 0.09 \\
\hline \multicolumn{14}{|c|}{ Panel B: Relative returns of small stocks over large stocks } \\
\hline$R_{\text {Smallt }+1}-R_{\text {Larget }+1}$ & 43 & -2.39 & {$[-3.79]$} & 0.09 & -2.18 & {$[-3.35]$} & 0.10 & 0.30 & {$[1.75]$} & 0.05 & 0.26 & {$[1.84]$} & 0.05 \\
\hline$R_{\text {Smallt }+2}-R_{\text {Larget }+2}$ & 42 & -4.42 & {$[-2.96]$} & 0.10 & -3.98 & {$[-2.46]$} & 0.10 & 0.47 & {$[1.87]$} & 0.04 & 0.40 & {$[1.80]$} & 0.03 \\
\hline$R_{\text {Smallt }+3}-R_{\text {Larget }+3}$ & 41 & -7.94 & {$[-3.00]$} & 0.18 & -7.21 & {$[-2.62]$} & 0.18 & 0.86 & {$[2.37]$} & 0.07 & 0.76 & [2.31] & 0.07 \\
\hline
\end{tabular}

